\title{
Três retratos em um retrato: No ateliê, de Arthur Timótheo da Costa
}

Three portraits in a portrait: No ateliê, by Arthur Timótheo da Costa

hitps://doi.org/10.1590/1982-02672020v28e55

\section{NATÁLIA CRISTINA AQUINO GOMES'}

hitps://orcid.org/0000-0002-5598-2027

Universidade Federal de São Paulo / Guarulhos, SP, Brasil

RESUMO: Dentre as várias imagens de ateliê e representações de artistas realizadas pelo pintor Arthur Timótheo da Costa (1 882-1922), este artigo trabalha com uma tela em que essa temática é evidenciada em muitos sentidos, principalmente no que diz respeito à representação do ateliê, como também ao registro de um artista trabalhando em uma obra e à presença do modelo nesta cena. Apresentaremos as hipóteses levantadas acerca da identificação dos representados pelo pintor: retratado e retratista. Da mesma maneira, abordaremos aspectos da produção artística do pintor e alguns dados relativos às relações travadas com artistas contemporâneos, assim como o diálogo com outras obras de sua autoria e da mesma temática.

PALAVRAS-CHAVE: Ateliê. Homenagem. Pintor. Representação. Retrato.

ABSTRACT: Among the various studio images and representations of artists by the painter Arthur Timótheo da Costa (1882-1922), this article is based on a painting in which this theme is evidenced in many ways, especially the representation of the studio and of an artist working, including the very presence of the model in this scene. We will present the hypotheses raised about the identification of those represented by the painter: portrayed and portraitist. In the same way,

\begin{abstract}
1. Mestra em História da Arte pelo Programa de Pós-Graduação em História da Arte da Universidade Federal de São Paulo (PPGHA-Unifesp), sob orientação da Profa. Dra. Elaine Dias, com apoio da Fundação de Amparo à Pesquisa do Estado de São Paulo (Fapesp). Bacharela em História da Arte pela Unifesp. E-mail: $<$ natalia.aquinog@gmail.com>.
\end{abstract}


we will cover aspects of the painter's artistic production and some data related to his relationships artists of the time, as well as the dialogue with other works of his own and the same theme.

KEYWORDS: Studio. Tribute. Painter. Representation. Portrait. 
A representação do ateliê do artista em diálogo com a dinâmica do ofício desenvolvido neste ambiente é um tema recorrente na produção artística de muitos pintores. Podemos encontrar um autorretrato tendo como plano de fundo esse ambiente - em uma espécie de afirmação da profissão - ou cenas de gênero que privilegiam modelos e pintores nesse espaço, assim como existem aqueles artistas que apresentam certa predileção pelo tópico e se voltam ao tema em vários momentos de sua trajetória. Este é o caso do pintor Arthur Timótheo da Costa $^{2}$ que, apesar da carreira interrompida precocemente, teve uma produção muito profícua e de destaque na cena artística do período.

Arthur Timótheo da Costa é um dos principais mestres brasileiros na representação do artista e do espaço do ateliê. $\bigcirc$ pintor realizou um número considerável de obras voltadas a esta temática, as quais versam sobre sua autorrepresentação, a representação de pintores anônimos no ateliê e de demais composições que tematizam o espaço de trabalho do artista, colocando-o no patamar de um mestre nesse seguimento. Seu interesse esteve expresso em seus autorretratos, assim como em obras onde não encontramos menção ao artista representado no título, mas que são evidentes como um ato de homenagem ou de afirmação de seus lugares no ambiente artístico. Este é o caso da obra No ateliê, pintura analisada neste artigo.

Para desvendar a composição e as intenções presentes na obra, iniciamos com breves aspectos sobre a biografia do artista, passando posteriormente à temática da representação do artista no ateliê, tema visitado por vários pintores e que também foi frequentado pelos brasileiros. Em seguida, analisamos a tela No ateliê, a fim de evidenciar as descobertas acerca dos personagens representados, assim como dialogamos com a repercussão da tela no período em que foi produzida. Da mesma forma, a relação de amizade mantida entre alguns pintores contemporâneos e as hipóteses para a realização dessa tela também são abordadas, questões centrais que permeiam boa parte das produções nesse campo. Cabe apontar ainda o fítulo deste artigo, que destaca a constituição da obra No Ateliê, isto é, uma tríplice representação: o artista que aparece em meio ao ofício; o modelo ao fundo, sentado em uma cadeira e o retrato executado em cena, o qual também discutimos ao longo do artigo. Por fim, verificamos outras obras de Arthur Timótheo da Costa que também retomam a temática da representação do artista e do ateliê, evidenciando, assim, seu interesse por essa tipologia e colocandoo como central na afirmação do gênero e da posição do artista. 
3. Cf. Amancio (2016).

4. Cf. Leite (1988, p. 216).

5. Cf. Levy (2003, p. 980).

6. Idem.

7. Óleo sobre tela, $186 \times 215$ cm, 1907. Acervo do Museu Nacional de Belas Artes, Rio de Janeiro. Disponível em: <https://bit.ly/35ci56M>. Acesso em: 11 nov. 2020.

8. Exposição... (1907).

9. Ibidem, p. 36.

\section{ARTHUR TIMÓTHEO DA COSTA - UMA BREVE BIOGRAFIA}

Pintor negro nasceu em 1882, no Rio de Janeiro, em uma família humilde. ${ }^{3}$ Irmão de João Timótheo da Costa (1 878-1932), que também construiu sua carreira como pintor, ambos fizeram parte do ambiente artístico do Rio de Janeiro, obtendo encomendas e conquistando a atenção da crítica. Conforme Leite, Artur Timótheo da Costa, ainda menino, atuou como auxiliar do cenógrafo italiano Orestes Coliva, especialista na feitura de panos de boca de teatros e cenários de ópera. Essa atuação certamente refletiu na obra do pintor, em sua "dramaticidade, o improviso e a agilidade na execução, sem falar nos efeitos espaciais". ${ }^{4}$ Tais aspectos sobressaem em suas obras e nas muitas representações de ateliês que o artista produziu ao longo de sua carreira.

$\bigcirc$ primeiro aprendizado dos irmãos deu-se na Casa da Moeda, local onde frequentavam o curso de desenho e aprendiam o processo de gravação de imagens e a impressão de moedas e selos, sob a direção de Ennes de Sousa. Ambos também estudaram na Escola Nacional de Belas Artes (ENBA). Lá, Arthur Timótheo obteve menção honrosa de primeiro grau no salão de $1906^{5}$ e, no ano seguinte, recebeu o prêmio de viagem à Europa ${ }^{6}$ com a obra Antes do Aleluia, ${ }^{7}$ após a desistência de Eduardo Bevilacqua. $\bigcirc$ prêmio havia sido entregue a Bevilacqua no ano anterior e não fora utilizado devido à perda repentina do pai, fato que o obrigou a permanecer no Rio de Janeiro para condução dos negócios da família. ${ }^{8}$ Assim, conforme menção no periódico Renascença sobre a Exposição de 1907: "O Director da Escola propoz então, em vista do parecer do Jury e approvação do Conselho Superior de Bellas Artes, que o governo da Republica fizesse recair o pensionato, não aproveitado, no Sr. Arthur Timotheo." 9

Após a premiação, precisamente em 1908, inicia-se a trajetória europeia do pintor, seguindo os estudos em Paris e lá permanecendo por cerca de dois anos, quando expõe no Salon francês, por exemplo. Além de realizar rápidas viagens à Espanha e à Itália, onde conhece e amplia seu repertório sobre os artistas consagrados e também tem contato com os colegas que igualmente transitavam pelo restante da Europa. Em 1911, integra o grupo de artistas escolhidos para executar a decoração do Pavilhão Brasileiro na Exposição Internacional de Turim.

De volta ao Brasil, dedica-se a afirmar e ampliar o lugar do artista na Sociedade Brasileira de Belas Artes, fundada em 1919 na cidade do Rio de Janeiro, e propõe, em 1920, uma participação livre dos artistas filiados à sociedade nas Exposições Gerais de Belas Artes. Sua trajetória segue na realização de pinturas, especialmente retratos, e executa ainda a decoração do salão nobre do Fluminense Football Club junto com o irmão, em 1920. Ainda 
que apresente suas obras na Exposição Geral de 1921, Arthur Timóteo acaba sendo internado no Hospício de Alienados do Rio de Janeiro, onde falece em 1922, interrompendo uma carreira de grande produção na sociedade carioca.

Nos últimos anos, a obra dos irmãos Timótheo da Costa vem sendo recuperada e ganhando destaque, como na mostra intitulada João e Arthur Timótheo da Costa. Os dois irmãos pré-modernistas Brasileiros, ${ }^{10}$ realizada no Museu Afro Brasil entre 2012 e 2013. No campo acadêmico, também é de se destacar as pesquisas que versam sobre a obra de Arthur Timótheo da Costa, entre elas estão a tese de Renata Bittencourt Um dândi negro: o retrato de Arthur Timótheo da Costa de Carlos Chambelland e a tese Reflexões sobre a pintura de Arthur Timótheo da Costa de Kleber A. de Oliveira Amancio. " Além desses, é o caso da dissertação Retrato de artista no ateliê: a representação de pintores e escultores pelos pincéis de seus contemporâneos no Brasil (1878-19191, da autora deste artigo, sendo que este é derivado dessa pesquisa de mestrado. ${ }^{12}$

\section{O ATELIÊ DO ARTISTA E A IMPORTÂNCIA DE SUA REPRESENTAÇÃO}

ateliê deve ser compreendido para além do espaço de trabalho do artista, tendo em vista os múltiplos usos do ambiente, pois o pintor ou escultor utiliza-o em seu benefício, em favor de sua própria arte. De acordo com Anne Martin-Fugier, "o ateliê é certamente uma realidade concreta. Mas na medida em que ele também é uma imagem do artista, devemos levar em conta sua representação". 13 Para analisarmos toda e qualquer representação de um ateliê, devemos entender o objetivo pretendido pelo artista autorrepresentado, ou representado por outro, através de sua imagem no ateliê, ou da representação da imagem de seu par, de seu colega, de seu homenageado. Nada era casual ou ingênuo. Tudo era pensado ou até mesmo encenado. Reforçando essa ideia, Lucy Peter menciona que, no século XIX, ocorreu uma profusão de imagens de ateliês de artistas: ${ }^{14}$

Imagens de artistas em seus ateliês não são de forma alguma uniformes e, embora, em alguns casos, sejam usadas como documentos históricos, sua veracidade é questionável. Por exemplo, enquanto alguns dos objetos incluídos em uma imagem do local de trabalho do artista são os objetos reais usados pelo artista nesse espaço, outros podem ter sido incluídos para sugerir algo sobre o estilo pessoal ou as conquistas artísticas do artista. ${ }^{15}$
10. Cf. Araujo (2012).

11. Bittencourt (2015); Amancio (2016).

12. Cf. Aquino Gomes (2019).

13. Martin-Fugier (2007, p. 88-89), tradução nossa.

14. Peter (2016, p. 105), tradução nossa.

15. Ibidem, p. 100, tradução nossa. 
16. Uma parceria da Pinacoteca do Estado de São Paulo com o Museu Nacional de Belas Artes do Rio de Janeiro, sob curadoria de Fernanda Pitta e cocuradoria de Ana Cavalcanti e de Laura Abreu. A exposição também esteve em cartaz no Museu Nacional de Belas Artes do Rio de Janeiro em 2019.

17. Ver o catálogo da exposição: Trabalho de Artista: imagem e autoimagem (1826-1929). Curadoria Fernanda Pitta, cocuradoria de Ana Cavalcanti e de Laura Abreu; textos Alain Bonnet... [et al.]. (Org.). 1ed. São Paulo: Pinacoteca de São Paulo, 2018.

18. Cf. Aquino Gomes (2019).

19. Óleo sobre tela, $320,5 \times 281,5 \mathrm{~cm}, 1656$. Acervo do Museu do Prado, Madri. Disponível em: $<$ https://bit.1y/3eEPIRW $>$. Acesso em: 11 nov. 2020.

20. Foucault (2000, p. 6).

21. Ibidem, p. 12.
Certamente, o poder simbólico do ateliê é inquestionável, tanto assim que o seu fascínio não se perdeu no tempo e continua presente em exposições e em pesquisas. No campo nacional, a popularidade do tema pôde ser vista recentemente na exposição Trabalho de artista: imagem e autoimagem (18261929), na Pinacoteca do Estado em São Paulo entre 2018 e 2019.16 Na ocasião, estiveram reunidas várias obras - pinturas, esculturas, gravuras e desenhos organizadas em quatro eixos: (1) Criação e ofício; (2) $\bigcirc$ ateliê como motivo; (3) A persona do artista (retratos e autorretratos); e (4) $\bigcirc$ artista e a modelo. ${ }^{17}$ No ateliê integrou a mostra, assim como outras obras de importantes artistas brasileiros, proporcionando um diálogo relevante para o estudo da temática.

O espaço do ateliê não pode ser compreendido como um lugar de passagem, mas sim de permanência e, acima de tudo, um local de domínio do artista - o seu recinto -, o ambiente em que ele trabalha, ensina e, por vezes, também, mora. Local onde comercializa sua arte, socializa com amigos, entregase a romances, usufrui de momentos familiares, propaga e legitima sua imagem por meio de retratos e registros fotográficos. É ainda o lugar onde recebe visitas de críticos, expõe sua arte em uma vitrine de produção exclusiva, tornando-o um local de exposições, entre outras atividades. Essas múltiplas características apontam a importância da temática do ateliê do artista e justificam o próprio interesse pelo espaço, que não se limitou somente à arte e às representações do espaço - feitas pelo próprio artista ou por um contemporâneo -, mas também alcançou outros segmentos que igualmente demonstraram interesse pela descrição e por sua imersão, como nos exemplos da literatura do século XIX onde o ateliê do artista faz-se cenário e protagonista dos romances. ${ }^{18}$

No caso de No ateliê, existe uma ambiguidade na representação do espaço que retoma algumas discussões acerca daquele que retrata, do retratado e do próprio retrato. Questões já presentes no quadro Las meninas, ${ }^{19}$ de Diego Velázquez. Em um texto homônimo contido em As palavras e as coisas, Michel Foucault desenvolve um ensaio sobre a obra. O autor olha e é olhado pelo quadro, e nos indaga: "Somos vistos ou vemos?". ${ }^{20}$ Nesse sentido, também nos questionamos ao olharmos para No ateliê: Qual relação ele mantém entre nós, espectadores, com o pintor retratado, com o artista que o retrata e com o modelo representado? Ainda que Foucault ressalte que "por mais que se diga o que se vê, o que se vê não se aloja jamais no que se diz", ${ }^{21}$ tentaremos, nesse artigo, jogar luz a algumas destas questões.

Nesse sentido, o ateliê pode ser pensado tanto como uma forma de explicitar a ilusão da representação quanto como o lugar insondável em que a representação é produzida, isto é, ele surge como o lugar da fantasia e da realidade, espaço em que $\mathrm{o}$ artista dá vida para sua imaginação. Dessa forma, pinturas como No ateliê e 
Las meninas, ainda que distantes temporalmente, oferecem possibilidades de investigação das dinâmicas e usos que os artistas fazem de seus ateliês, assim como os significados por trás da escolha de realizar uma obra em que o plano de fundo se confunde com o centro da obra, isto é, seu próprio ambiente de trabalho.

\section{NO ATELIÊ: A REPRESENTAÇÃO DE UMA REPRESENTAÇÃO}

Na obra No ateliê (Figura 1), de 1918, vemos, no primeiro plano, um pintor vestindo camisa branca, gravata, colete e calças de tonalidade escura sentado em uma cadeira com alguns tecidos que recaem de seu encosto. $\bigcirc$ pintor está de perfil, com sua atenção voltada à tela disposta no cavalete à sua frente, um retrato. Em sua mão esquerda, há uma paleta com quatro pincéis e na direita outro pincel, que o pintor aplica sobre a pintura. Na tela, dentro deste quadro, observamos o retrato de um homem também sentado e, na cadeira ao fundo, no canto direito do quadro, vemos o modelo posando. Chama a atenção o fato de o pintor, apesar de ter retirado o terno, não ter protegido suas roupas com algum avental/jaleco. Estaria ele somente retocando sua obra? No entanto, observamos que o retrato no qual o pintor trabalha está praticamente acabado. Percebemos ainda alguns detalhes do ambiente, como a luz oriunda do fundo do retrato, que revela alguns objetos e mobiliários dispostos no cômodo, como a cartola depositada em um pequeno móvel localizado no centro do quadro, próximo ao modelo que posa para o retrato, seu possível proprietário. Vemos também uma escultura depositada neste mesmo móvel e podemos ver seu verso, o que nos faz pensar que ela esteja diante de um espelho e, próximo a estes objetos, notamos no chão a presença de uma tela emoldurada e de uma máscara pendurada na pilastra atrás do móvel.

Esse quadro de Arthur Timótheo da Costa ingressou em 2001 na coleção de pintura brasileira da Pinacoteca de São Paulo, por meio de uma doação da Bolsa de Arte do Rio de Janeiro. A tela, originalmente "Sem título", teve sua nova atribuição como No ateliê em razão da pesquisa para exposição de longa duração do acervo. ${ }^{22}$ Nesse sentido, não existia até então menção à identidade do pintor retratado, o que nos leva a discutir a questão do anonimato e se este retrato possuía ou não alguma identificação do retratado e se a mesma se perdeu ao longo dos anos.

$\bigcirc$ quadro dentro do quadro (Figura 2) - para usarmos uma expressão cara a André Chastel $-{ }^{23}$ que aparece em No ateliê existiu realmente, ${ }^{24}$ embora não saibamos sua localização ou se sobreviveu ao tempo. Trata-se da obra Retrato do Conde de Vasconcellos (Figura 3), da qual resta somente a imagem
22. Consulta realizada a Ficha catalográfica da obra (PINA05173) extraída da base de dados da Pinacoteca do Estado, InPatrimonium.net. Agradecemos à pesquisadora Gabriela Pessoa de Oliveira, que nos recebeu no Núcleo Acervo Museológico da instituição, em 25 de julho de 2017.

23. Chastel (2000, p. 80).

24. Agradecemos ao pesquisador João Victor Rossetti Brancato por chamar atenção para este detalhe que nos levou a outras informações e descobertas. 
publicada na Illustração Brasileira, na edição de setembro de 1923, em uma matéria sobre o "Atelier Rodolpho Chambelland".

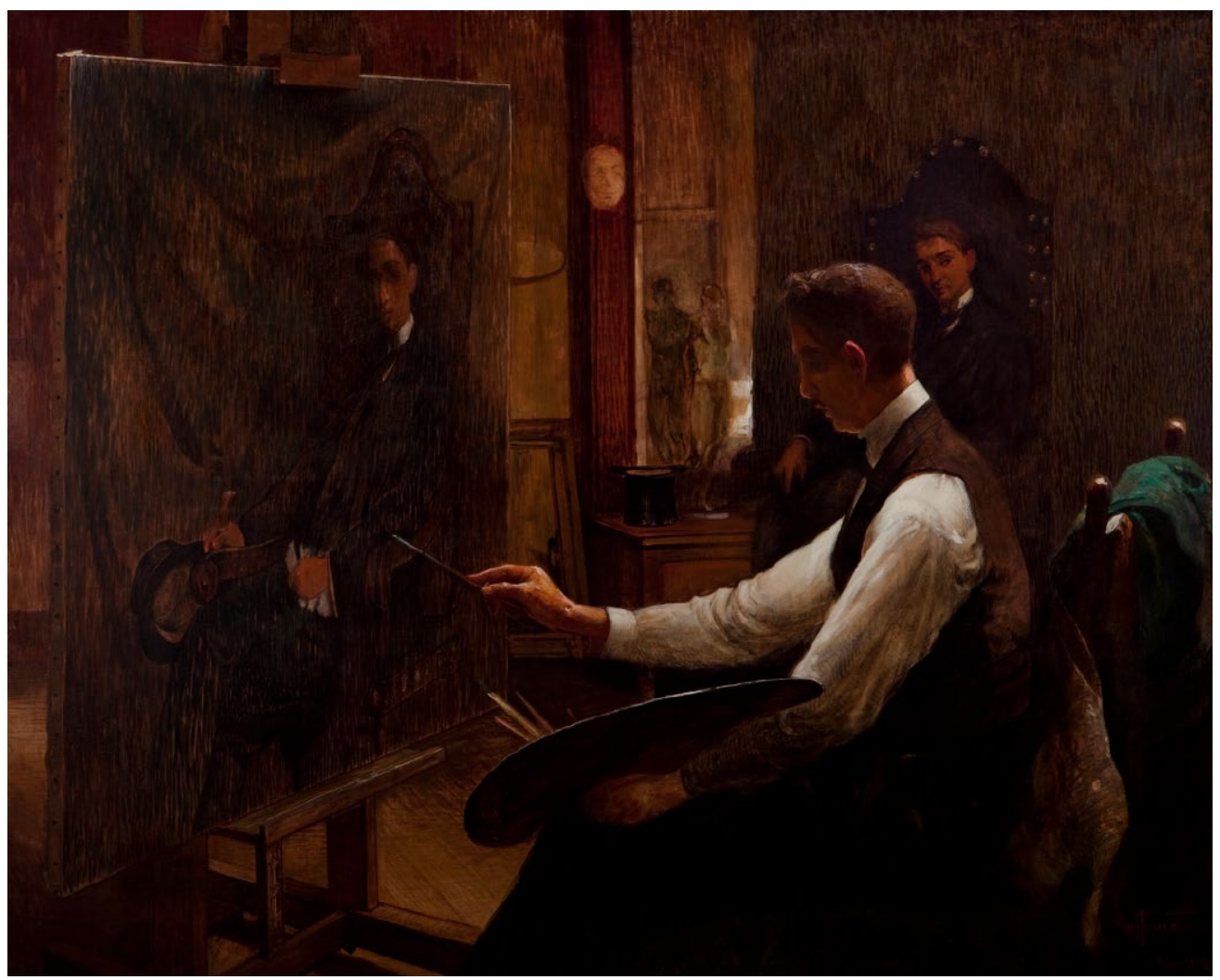

Figura 1 - No ateliê, Arthur Timótheo da Costa, 1918. Óleo sobre tela, 195×158 cm. Fonte: Pinacoteca do Estado de São Paulo, São Paulo. Foto: Isabella Matheus. Reprodução autorizada pela Pinacoteca de São Paulo.

Podemos supor que o artista retratado pintando o quadro (Figura 4 e Figura 5) seja o próprio Rodolpho Chambelland (1879-1967) (Figura 6 e Figura 7), que no ano de 1918 participou da XXV Exposição Geral de Belas Artes com o quadro Retrato do barão S. de V. ${ }^{25}$ Este era possivelmente o retrato do Barão Jayme Smith de Vasconcellos que, na imagem referenciada acima, traria erroneamente o título de Conde e não o de Barão como the fora herdado. 


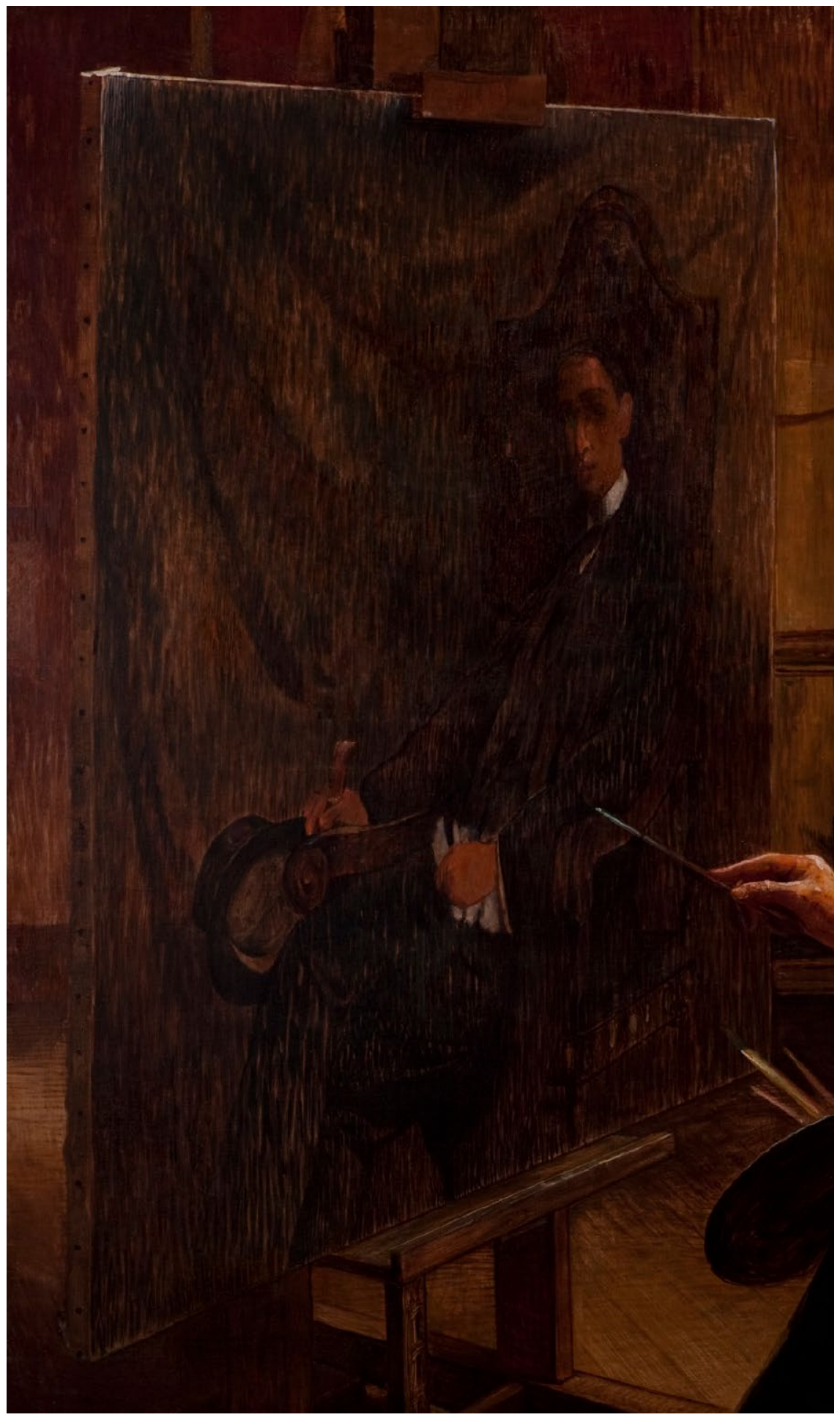

Figura 2 - Detalhe de No ateliê, Arthur Timótheo da Costa, 1918. Fonte: Pinacoteca do Estado de São Paulo, São Paulo. Foto: Isabella Matheus. Reprodução autorizada pela Pinacoteca de São Paulo. 


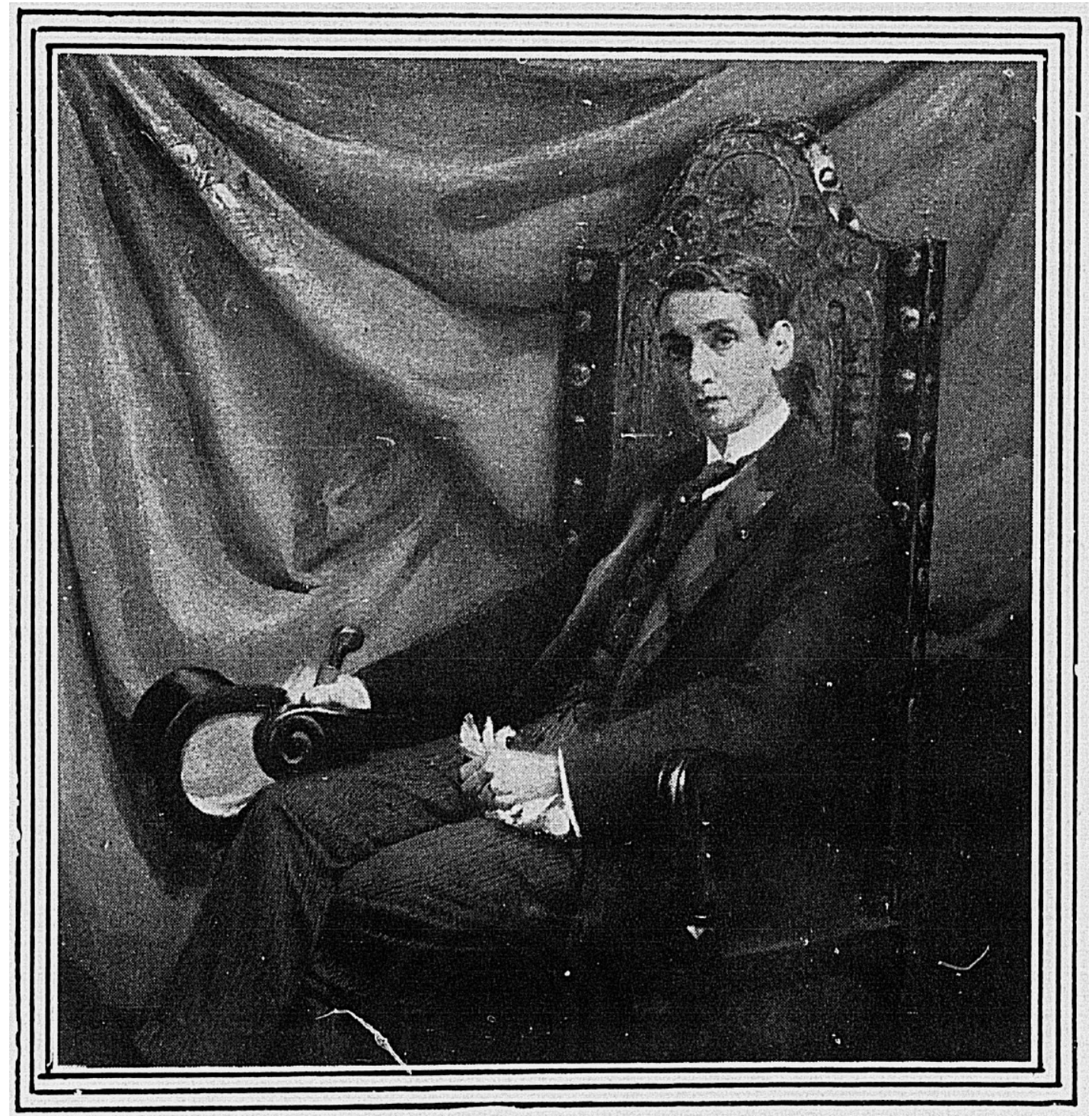

"RETRATO DO CONDE DE VASCONCELLOS"

Figura 3 - Retrato do Conde de Vasconcellos, Rodolpho Chambelland, s. d. Fonte: Cremona (1923, p. 21). 


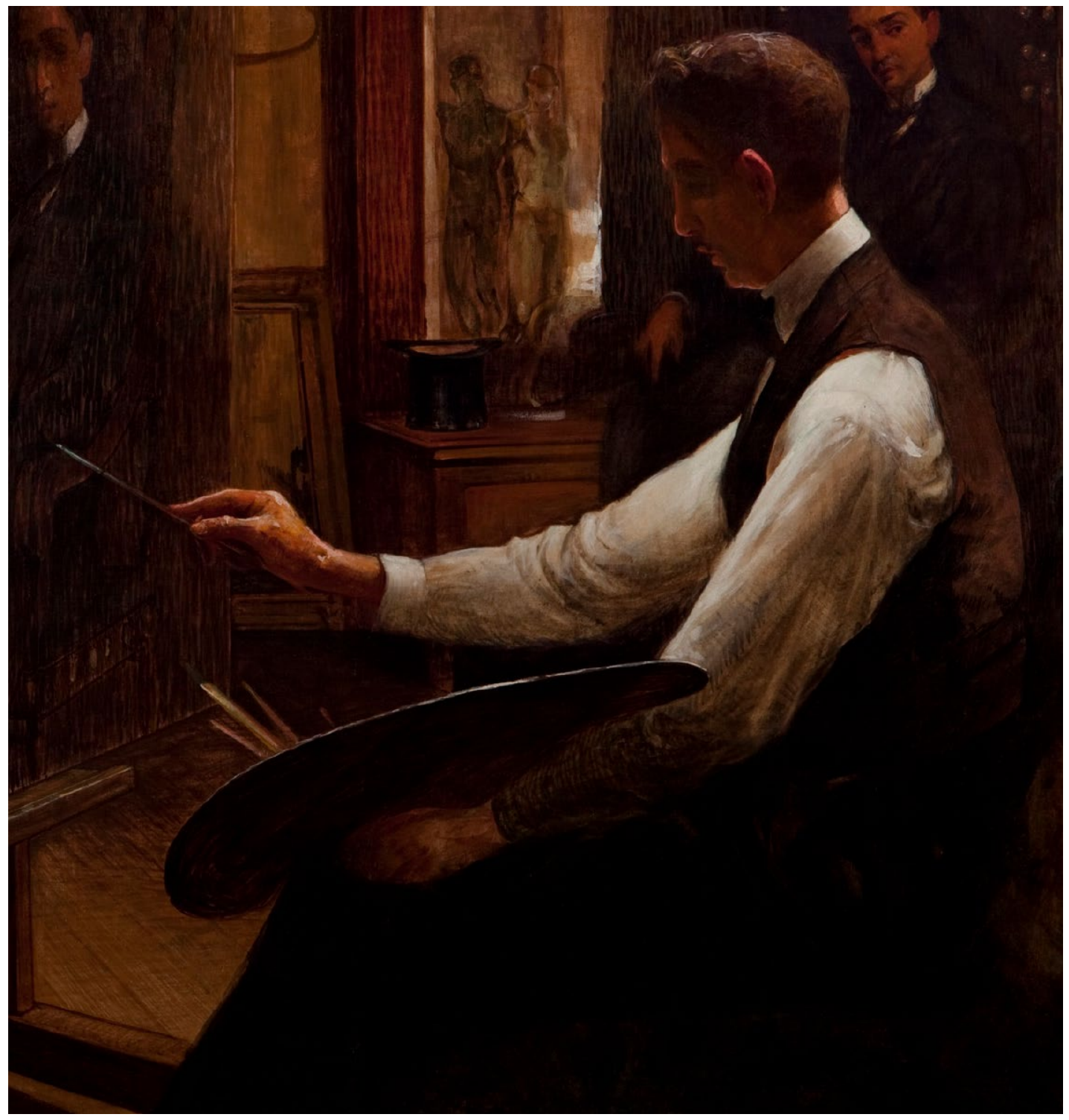

Figura 4 - Detalhe de No ateliê, Arthur Timótheo da Costa, 1918. Fonte: Pinacoteca do Estado de São Paulo, São Paulo. Foto: Isabella Matheus. Reprodução autorizada pela Pinacoteca de São Paulo. 


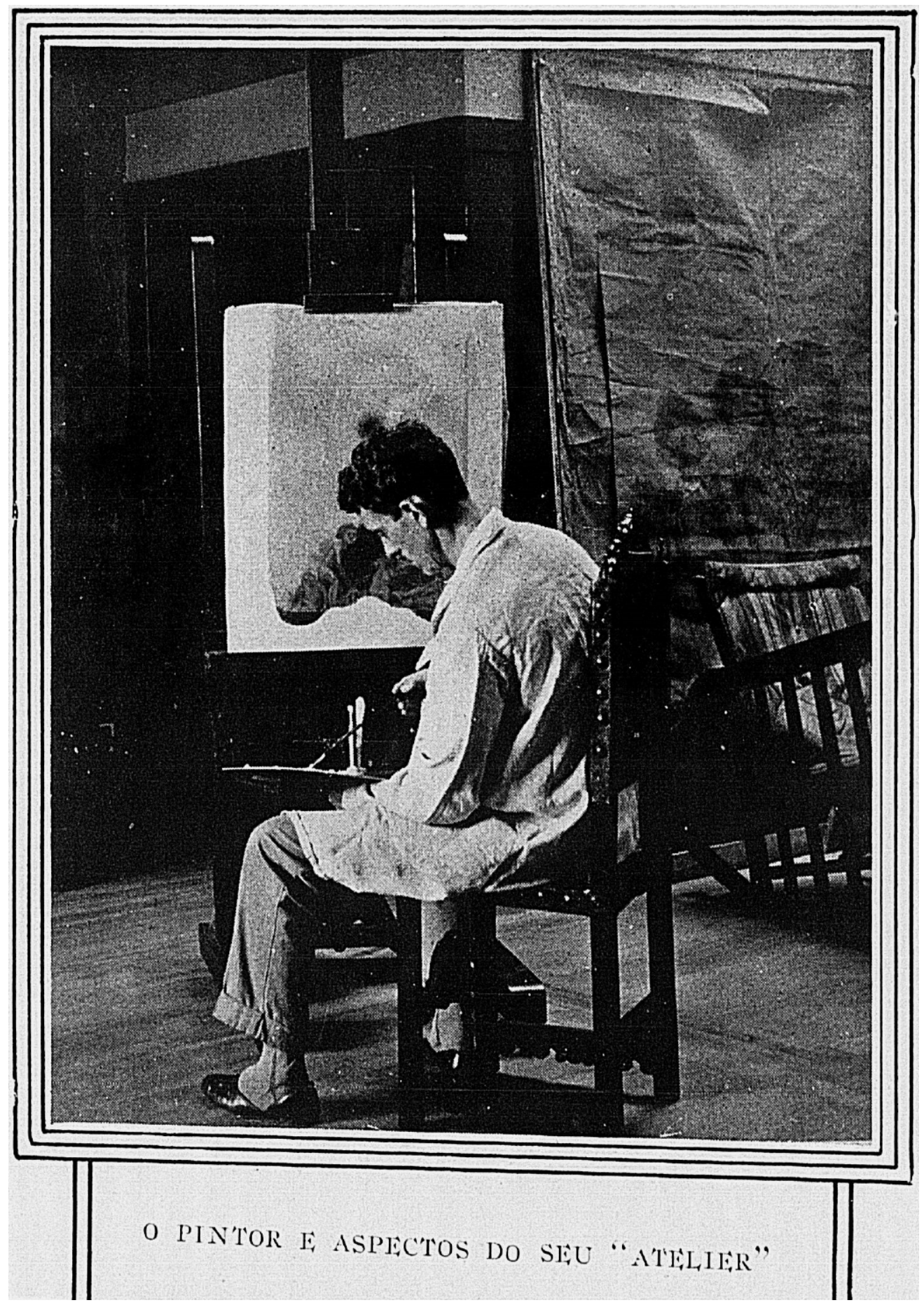

Figura 5 - O pintor e aspectos do seu "Atelier", representando Rodolpho Chambelland. Fonte: Cremona (1923, p. 20). 


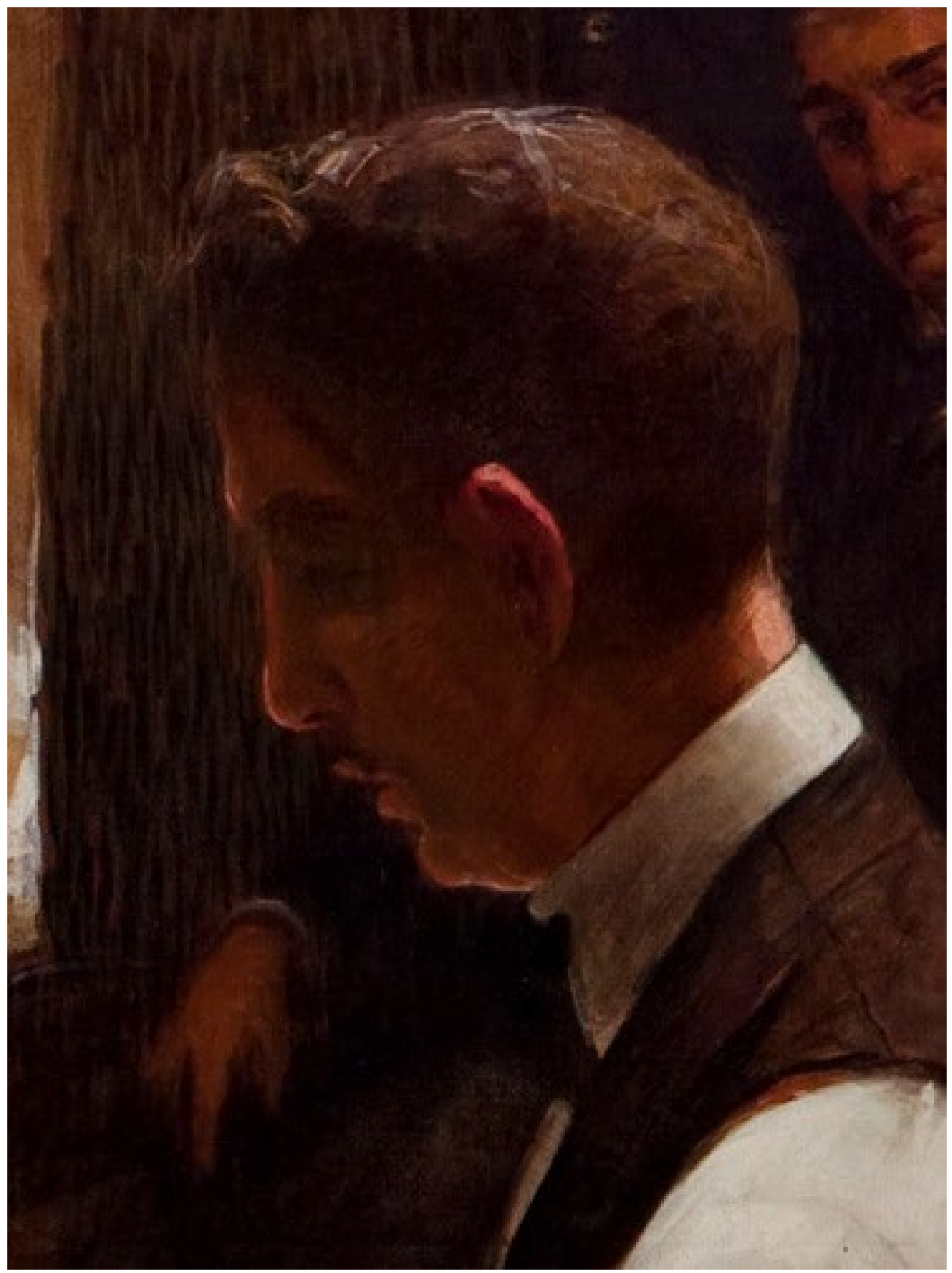

Figura 6 - Detalhe de No ateliê, Arthur Timótheo da Costa, 1918. Fonte: Pinacoteca do Estado de São Paulo, São Paulo. Foto: Isabella Matheus. Reprodução autorizada pela Pinacoteca de São Paulo. 


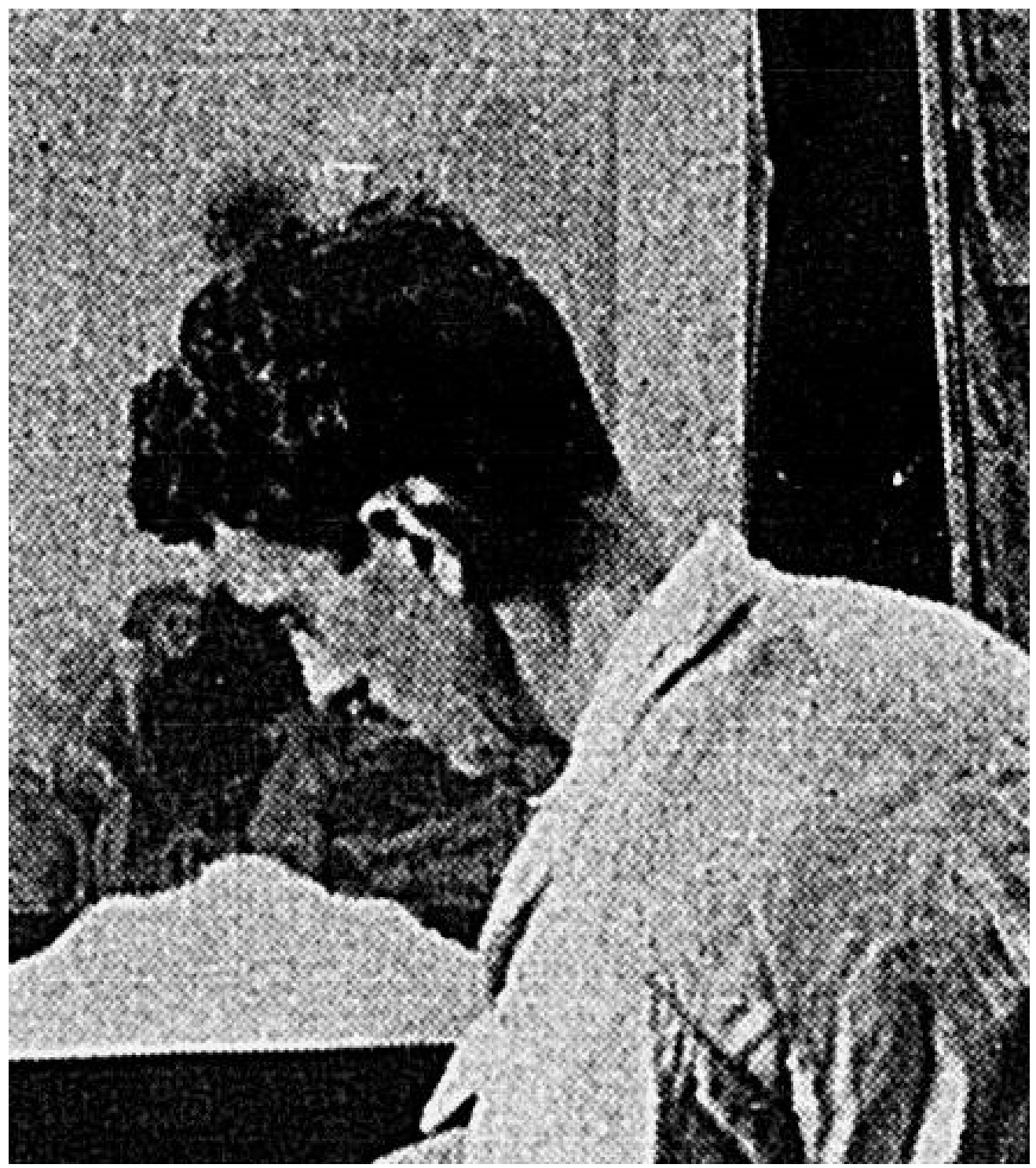

Figura 7 - Detalhe de O pintor e aspectos do seu "Atelier". Fonte: Cremona (1923, p. 20).

O BARÃO DE VASCONCELLOS, OS ASPECTOS DE SUA RESIDÊNCIA E UMA REFLEXÃO ATRAVÉS DE UMA PEÇA DE MOBILIÁRIO

Jayme Luiz Smith de Vasconcellos foi o $3^{\circ}$ Barão de Vasconcellos, título herdado de seu pai Rodolpho Smith de Vasconcellos, $2^{\circ}$ Barão de Vasconcellos que, por sua vez, recebeu o título nobiliárquico de seu pai José Smith de 
Vasconcellos, $01^{\circ}$ Barão de Vasconcellos. ${ }^{26}$ Encontramos uma imagem do Barão J. Smith de Vasconcellos (Figura 8) que se aproxima muito daquela do homem posando para o retrato sentado na cadeira ao fundo de No ateliê (Figura 9). Vemos similaridade ao compararmos estas duas imagens tomadas em ângulos parecidos, que privilegiam a face masculina, e, desta maneira, torna-se possível a observação de alguns detalhes, como o corte de cabelo e penteado semelhante, os mesmos traços faciais e alguns indícios de sua vestimenta bem composta, da qual se projeta o colarinho alto de sua camisa branca envolta pela gravata com o impecável nó ao centro, e pelo paletó de tonalidade escura.

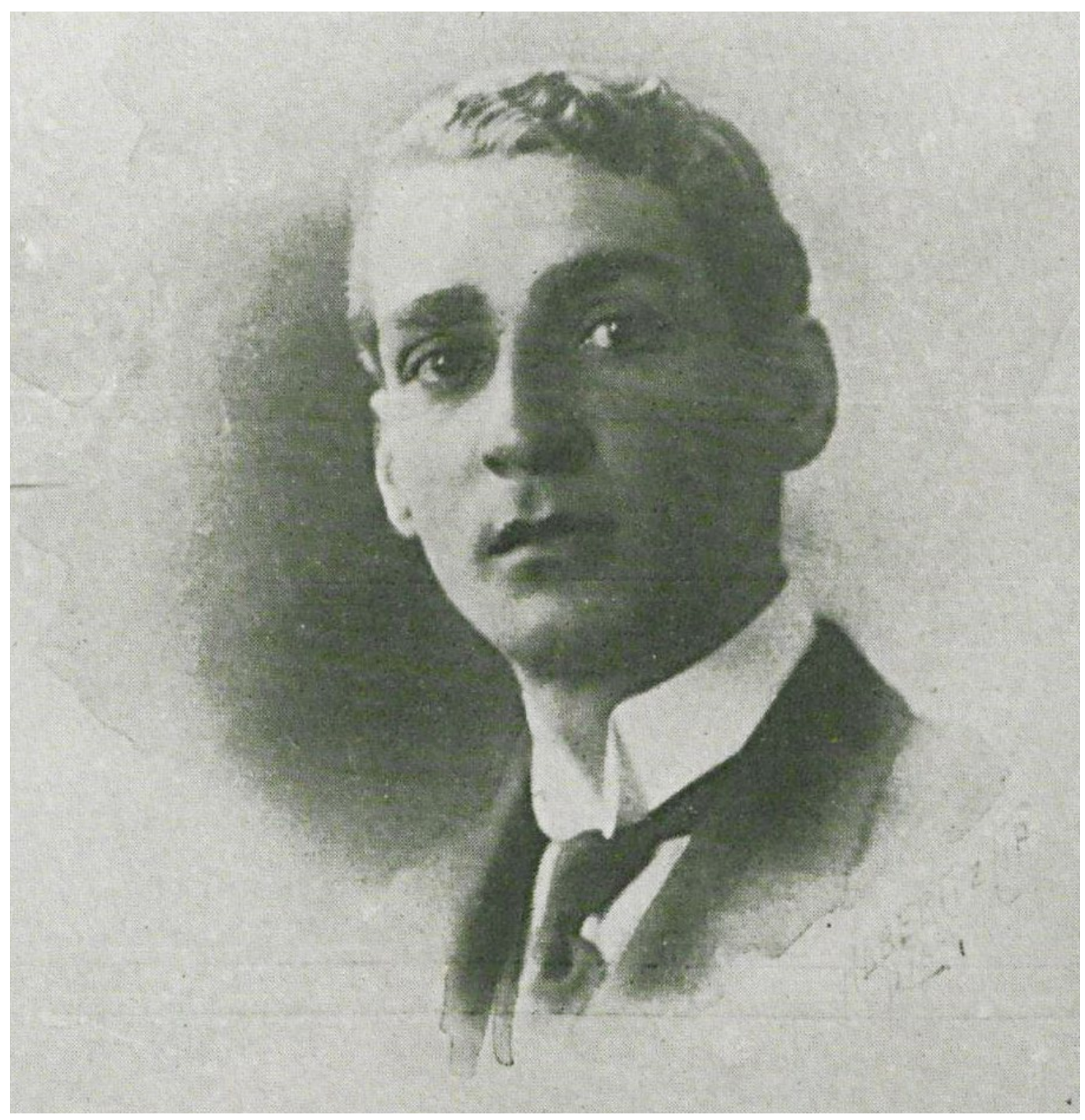

Figura 8 - Barão J. Smith de Vasconcellos. Fonte: Vasconcellos; Bragança (1919, p. 11 ).
26. Vasconcellos; Vasconcellos (1918, p. 529-531) 


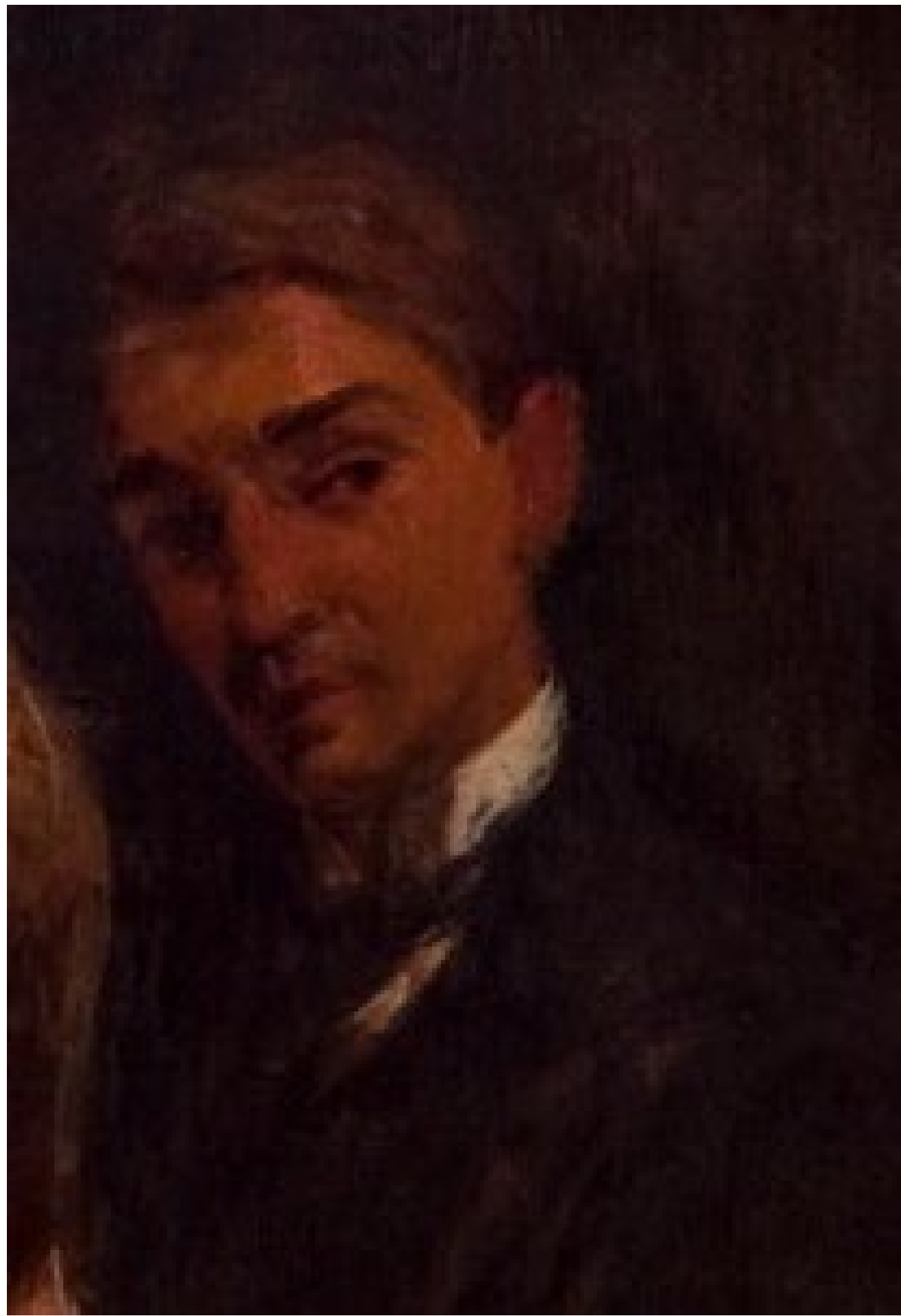

Figura 9 - Detalhe de No ateliê, Arthur Timótheo da Costa, 1918. Fonte: Pinacoteca do Estado de São Paulo, São Paulo. Foto: Isabella Matheus. Reprodução autorizada pela Pinacoteca de São Paulo. 
Outro aspecto levantado diz respeito à cadeira onde o Barão de Vasconcellos aparece sentado, que muito se assemelha a uma das cadeiras que aparecem dispostas na biblioteca de sua propriedade, na Avenida Atlântica, no Rio de Janeiro. ${ }^{27} \mathrm{Na}$ imagem, extraída de A Cigarra em matéria sobre "Vivendas Pitorescas" (Figura 10), vemos alguns detalhes do que seria a biblioteca de sua propriedade e nos chama a atenção a existência de cadeiras (Figura 11) que seguem o mesmo padrão estilístico daquela representada no Retrato de Conde de Vasconcellos e também em No ateliê (Figura 12), com o mesmo encosto ornado com pregaria de metais em formato circulares por toda a sua extensão.

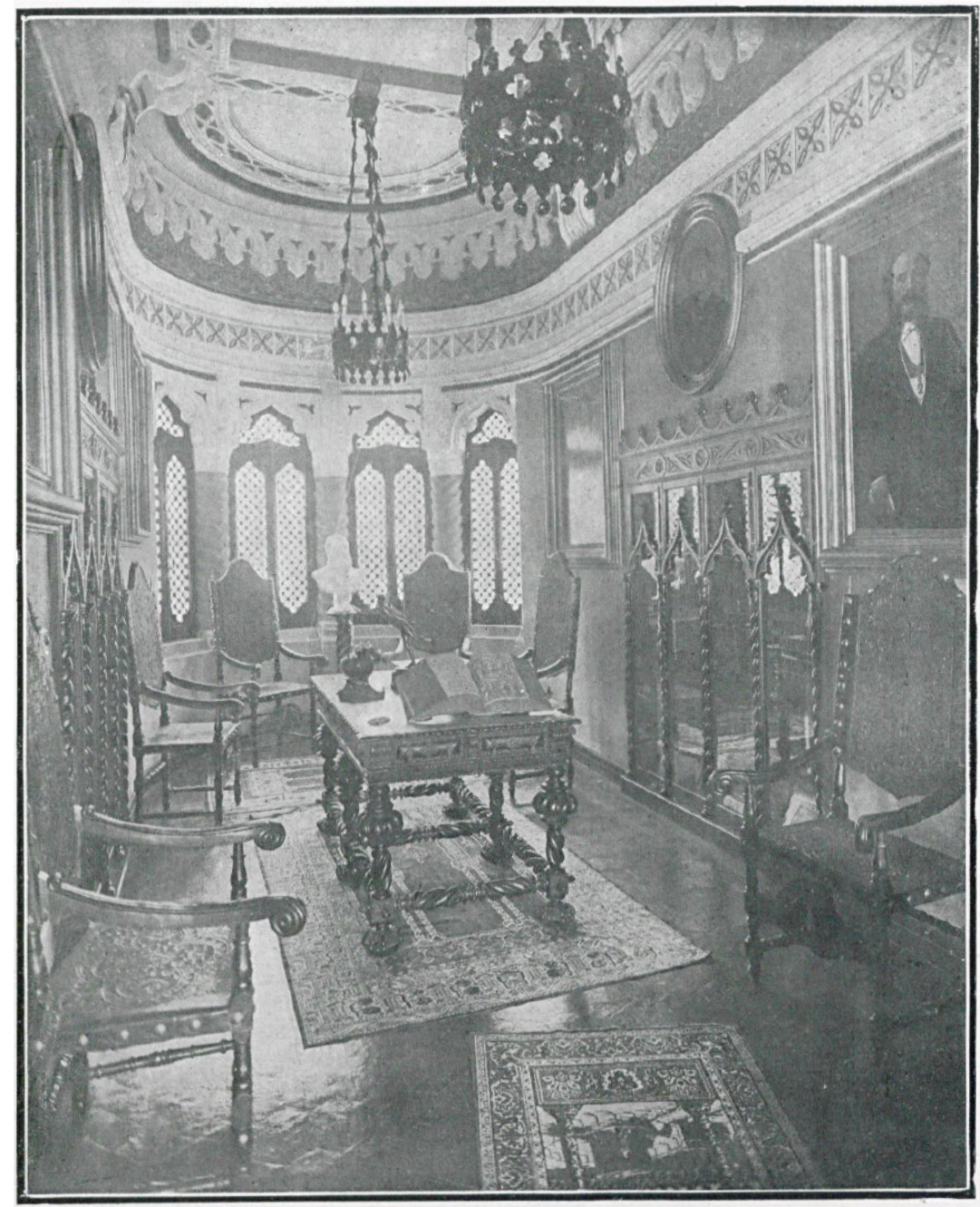

A bibliotheca da "Villa S. José,.. na Avenida Atlantica, de propriedade do sr. Barão Jayme Smith de Vasconcellos.
27. O projeto da residência do Barão de Vasconcellos é de autoria do arquiteto italiano Antonio Virzi, que veio para o Brasil por volta de 1910. Foi o responsável por vários projetos, principalmente no Rio de Janeiro, onde também ocupou a cadeira de arquitetura, por indicação do diretor Rodolfo Bernardelli. Acerca do palacete, Arestizábal e Grinberg mencionam que a: "Casa Smith de Vasconcellos, [...] Virzi construiu na Av. Atlântica n. 680, para o Barão Smith de Vasconcellos, este 'castelinho' de paredes ocres e janelas azuis que foi destruído em 1964. As formas florentinomedievais misturaram-se ao movimento criado pelo teto em forma de concha, pelo pórtico curvo [...] pelos ferros que enfeitam as sacadas e terraços, pela escada em caracol [...] pela iluminação 'moderna' dada pela claraboia e pelas decorações 'clássicas' de algumas salas do interior" (1989, p. 10).

Figura 10 - Biblioteca da propriedade do sr. Barão Jayme Smith de Vasconcellos. Fonte: Vivendas... (1917, p. 28). 
Figura 11 - Detalhe de uma cadeira da biblioteca da propriedade do sr. Barão Jayme Smith de Vasconcellos. Fonte: Vivendas... (1917, p. 28).
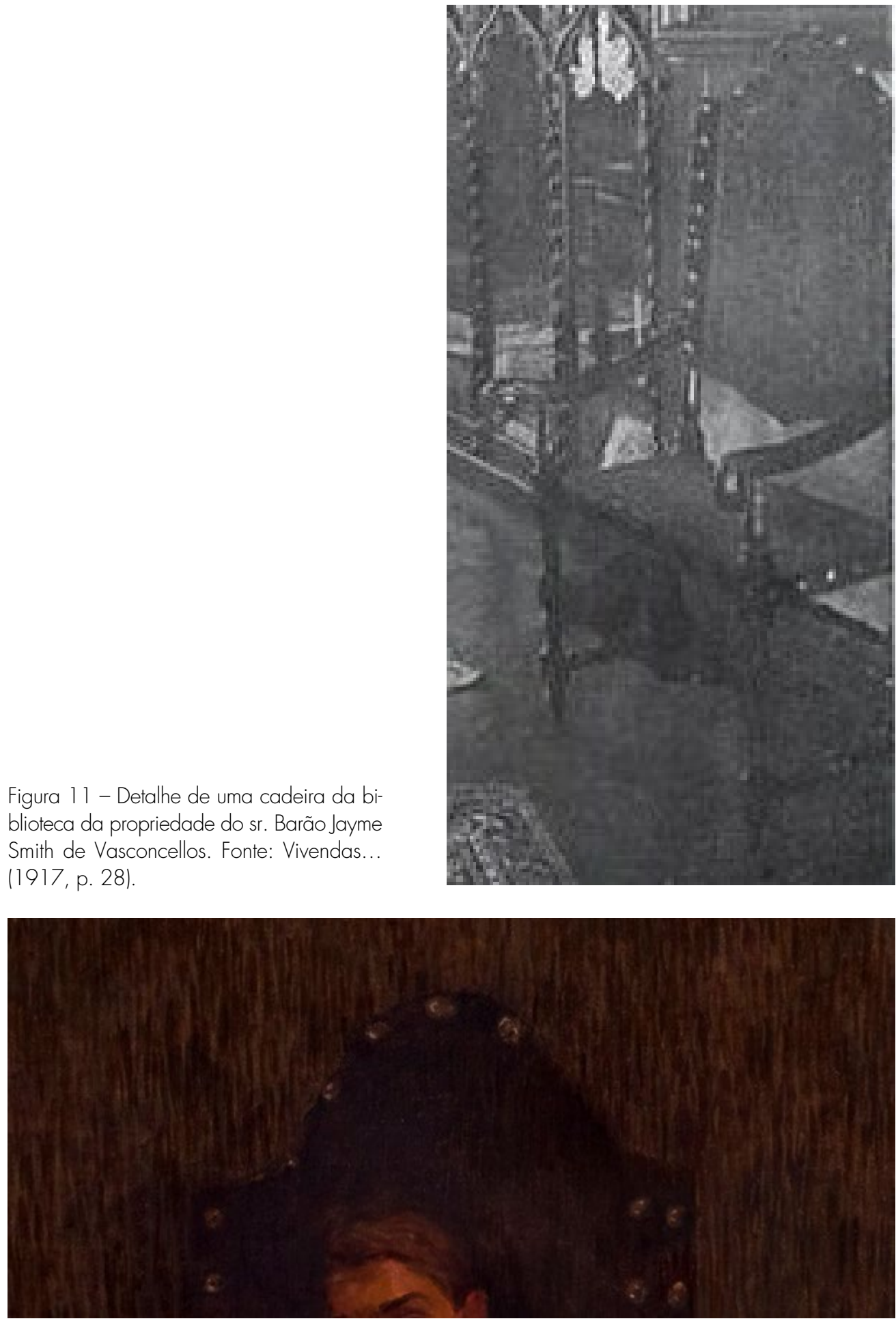

Figura 12 - Detalhe de No ateliê, Arthur Timótheo da Costa, 1918. Fonte: Pinacoteca do Estado de São Paulo, São Paulo. Foto: Isabella Matheus. Reprodução autorizada pela Pinacoteca de São Paulo. 
Identificamos o estilo desta cadeira e encontramos no Catalogo illustrado da exposição retrospectiva de arte ornamental portugueza e hespanhola celebrada em Lisboa em 1882 um desenho de uma "cadeira de nogueira com assento e costas de couro" 28 semelhante à representada no quadro e também muito próxima daquela presente na biblioteca do Barão Smith de Vasconcellos. Identificamos cadeiras semelhantes em endereços eletrônicos de Casas de Leilões e Antiguidades localizadas em Lisboa, ${ }^{29}$ datando-as entre os séculos XVIII e XIX. Nesse sentido, podemos dizer que a cadeira presente no quadro de Arthur Timótheo e também aquelas localizadas na biblioteca do Barão teriam origem portuguesa. A família Vasconcellos é natural de Lisboa e, mesmo o $3^{\circ}$ Barão de Vasconcellos tendo nascido no Rio de Janeiro, ${ }^{30}$ muito provavelmente manteve contato com Portugal e com seus familiares realizando viagens, momento em que pode ter adquirido exemplares das cadeiras aqui analisadas ou mesmo importado algumas para seguir tal moda.

O Museu da Casa Brasileira (MCB) conserva um exemplar deste tipo de cadeira, que no catálogo de seu acervo aparece como "poltrona de couro com pregaria, século XVIII", sendo ela:

Confeccionada em carvalho madeira estrangeira, é um exemplar do estilo Nacional-Português, de características austeras, com influência renascentista. A ornamentação no couro gravado do encosto é rica e identificada como indo-portuguesa, pelo tratamento compositivo do vaso de flores ladeado por meninos segurando ramagens, com detalhes rendilhados e simétricos. $\bigcirc$ aspecto garante formalidade, mas não conforto. ${ }^{31}$

Maria Angélica Santi em Mobiliário no Brasil: origens da produção e da industrialização, ao mencionar essa tipologia de cadeira presente na coleção do MCB, ${ }^{32}$ afirma que esta seria:

Outro exemplo do mobiliário desse período que, [...] apresenta maior requinte na elaboração da peça, embora a composição continue retangular: cadeira com espaldar alto, encosto e assento em couro gravado com motivos decorativos fitomorfos, formas humanas geometrizadas são fixados por pregaria nas prumadas finalizadas em carapetas metálicas; o assento já se apresenta ligeiramente trapezoidal, o que indica uma evolução; os pés lisos são substituídos por outros mais trabalhados; a testeira, amarração que une os pés frontais, é entalhada em forma de SS invertido. ${ }^{33}$

Estas informações acerca da tipologia da cadeira interessam-nos na medida em que procuramos aprofundar a questão do mobiliário utilizado em bibliotecas e
28. Catalogo... (1882, n. 207).

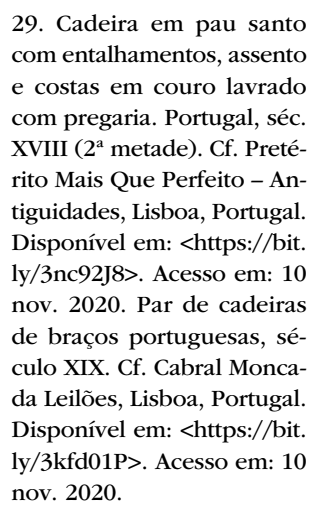

29. Cadeira em pau santo com entalhamentos, assento e costas em couro lavrado com pregaria. Portugal, séc. XVIII ( $2^{\mathrm{a}}$ metade). Cf. Pretérito Mais Que Perfeito - Antiguidades, Lisboa, Portugal. Disponível em: <https://bit. ly/3nc92J8>. Acesso em: 10 nov. 2020. Par de cadeiras de braços portuguesas, século XIX. Cf. Cabral Moncada Leilões, Lisboa, Portugal. Disponível em: <https://bit. ly/3kfd01P>. Acesso em: 10 nov. 2020.

30. Cf. Vasconcellos; Vasconcellos (1918, p. 529531).

31. Cf. Borges (2007, p. 33).

32. Leia-se na legenda: "Figuras 12 e 12a. Cadeira de braço, século XVIII. Acervo Museu da Casa Brasileira, São Paulo/SP. Doação de Alfredo Mesquita. Feita em Jacarandá, couro e metal na pregaria. Dimensões: $103 \times 51,5 \times 50 \mathrm{~cm}$. Fotografia: Marcelo Andrade" Santi (2013, p. 61).

33. Ibidem, p. 60. 
34. Malta (2011, p. 91-94).

35. Ibidem, p. 92.

36. Identificamos no Real Gabinete Português de Leitura, no centro do Rio de Janeiro, cadeiras semelhantes a estas, o que certamente comprova seu uso no mobiliário de bibliotecas e sua origem portuguesa. O Real Gabinete Português de Leitura foi inaugurado em 1887 e transformado em biblioteca pública em 1900. Cf.: <https://bit. ly/32wwJE8>. gabinetes de trabalho chamados por Marize Malta de "salas para pensar". ${ }^{34}$ Para a autora, as bibliotecas seriam:

Para os homens de estudos, ligados à ciência e às letras, uma biblioteca seria complemente irrefutável de seus gabinetes. Guardiã de livros, lugar de espíritos cultivados, de homens que pensam e refletem eis como a biblioteca era vista [...] Os móveis seriam distintos, com cadeiras robustas, de variados formatos e com farto estofado. [...] Nas bibliotecas, nada de cadeiras muito confortáveis, pois induziriam ao sono mais do que ao estudo. ${ }^{35}$

Nesse sentido, e como já fora observado na descrição presente no catálogo do $M C B$, esse tipo de cadeira não seria propriamente confortável e, apoiado nas considerações de Malta, acreditamos que estas certamente poderiam ser utilizadas em bibliotecas. ${ }^{36}$ Desta forma, a presença de cadeiras desse estilo na biblioteca do retratado talvez aponte que o Barão Smith de Vasconcellos tenha posado para seu retrato em sua residência e o espaço que pensamos reconhecer como ateliê no quadro de Arthur Timótheo pode ser um dos cômodos da propriedade do Barão, possivelmente sua biblioteca particular, transformada em ateliê para a tela realizada por Rodolpho Chambelland.

Contudo, existe ainda a possibilidade do retrato do Barão Smith de Vasconcellos ter sido produzido após sessões de poses realizadas na residência do próprio barão e que Arthur, quando compôs seu quadro e de posse da imagem do retrato feito por Chambelland, tenha reproduzido o retrato de Vasconcellos e a sessão de pose, de forma a nos passar a impressão de que o modelo, o barão, estivesse ali naquele momento sentado enquanto o artista terminava seu retrato. É possível também que Arthur tivesse de fato acompanhado uma das sessões de pose na casa de Vasconcellos e reproduzido a cena em seu quadro. Considerando outras possibilidades, também há a hipótese de que Arthur não tenha presenciado, mas inventado ou imaginado como teria sido essa sessão de pose representada em No ateliê. Estas são hipóteses, para as quais faltam dados que as comprovem, no entanto destacamos que a imagem da biblioteca do Barão Smith de Vasconcellos circulou na revista A Cigarra de 1917 e que Chambelland apresentou no Salão de 1918 o Retrato do barão S. V., ou seja, provavelmente a decoração da residência continuou da mesma forma, inclusive as cadeiras que, em um primeiro momento, acreditamos se adequarem mais ao palacete do barão do que propriamente ao ateliê de um pintor.

Os ateliês dos artistas também tinham, no entanto, cadeiras desse estilo, o próprio Rodolpho Chambelland tinha em seu ateliê cadeiras similares as quais analisamos (Figura 13), mas sem a presença dos braços laterais. Já no ateliê de 
Henrique Bernardelli (1857-1936) (Figura 14), identificamos uma cadeira muito semelhante, o que certamente revela um gosto dos artistas por esse estilo, que também aparece em uma fotografia do pintor João Baptista da Costa (18651926) (Figura 15) e no Retrato de Georgina, ${ }^{37}$ feito por Lucílio de Albuquerque. Talvez a representação tematizada em No ateliê possa ter ocorrido no ateliê de Rodolpho Chambelland, responsável pelo retrato de Vasconcellos, ou até mesmo no ateliê de Arthur Timótheo, autor da composição final aqui analisada. Nesta perspectiva, não podemos deixar de pontuar a importância do mobiliário e da modernidade que estes incorporam ao retrato e ao retratado.

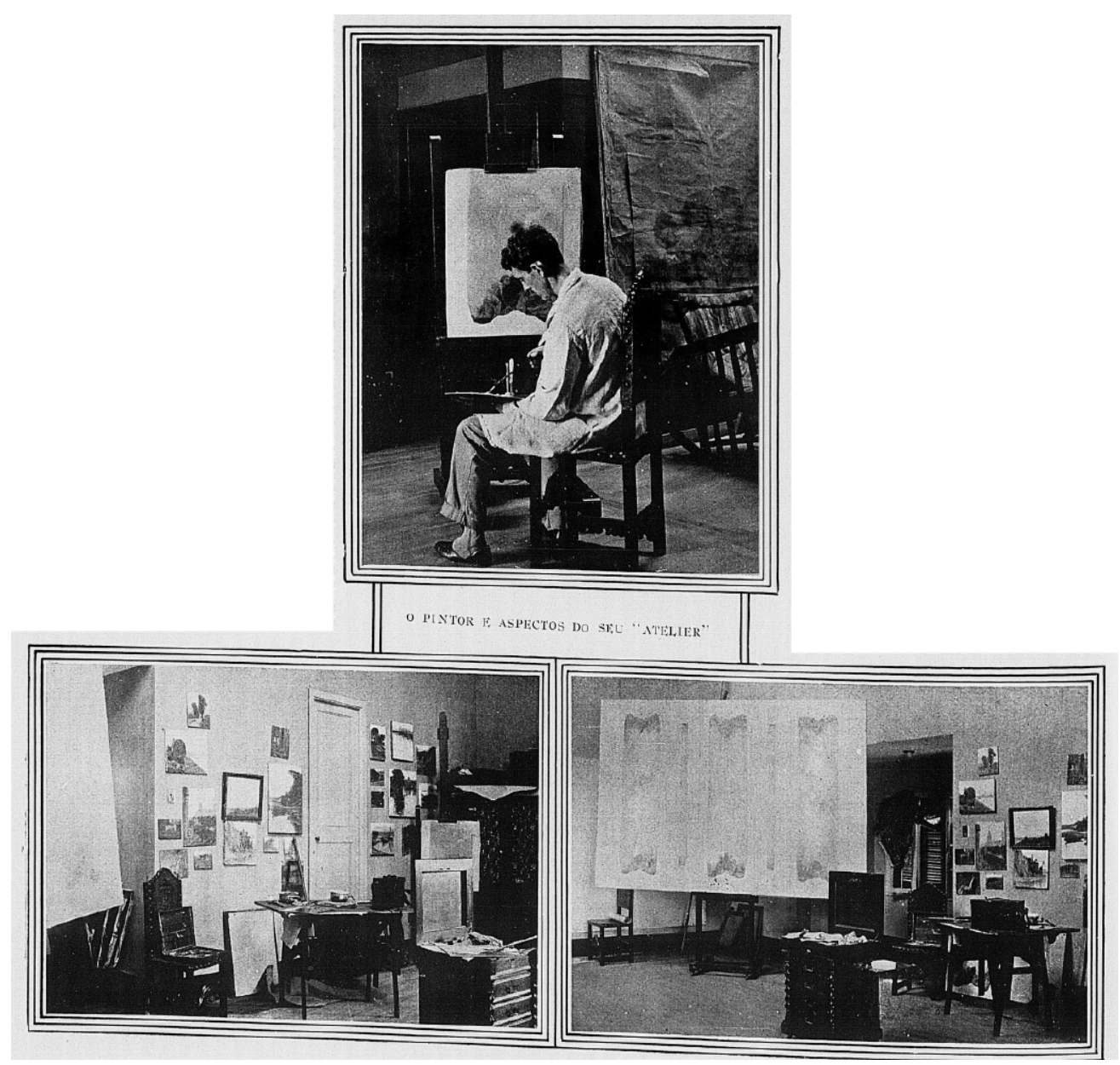

Figura 13 - O pintor e aspectos do seu "Atelier", representando Rodolpho Chambelland. Fonte: Cremona (1923, p. 20). 


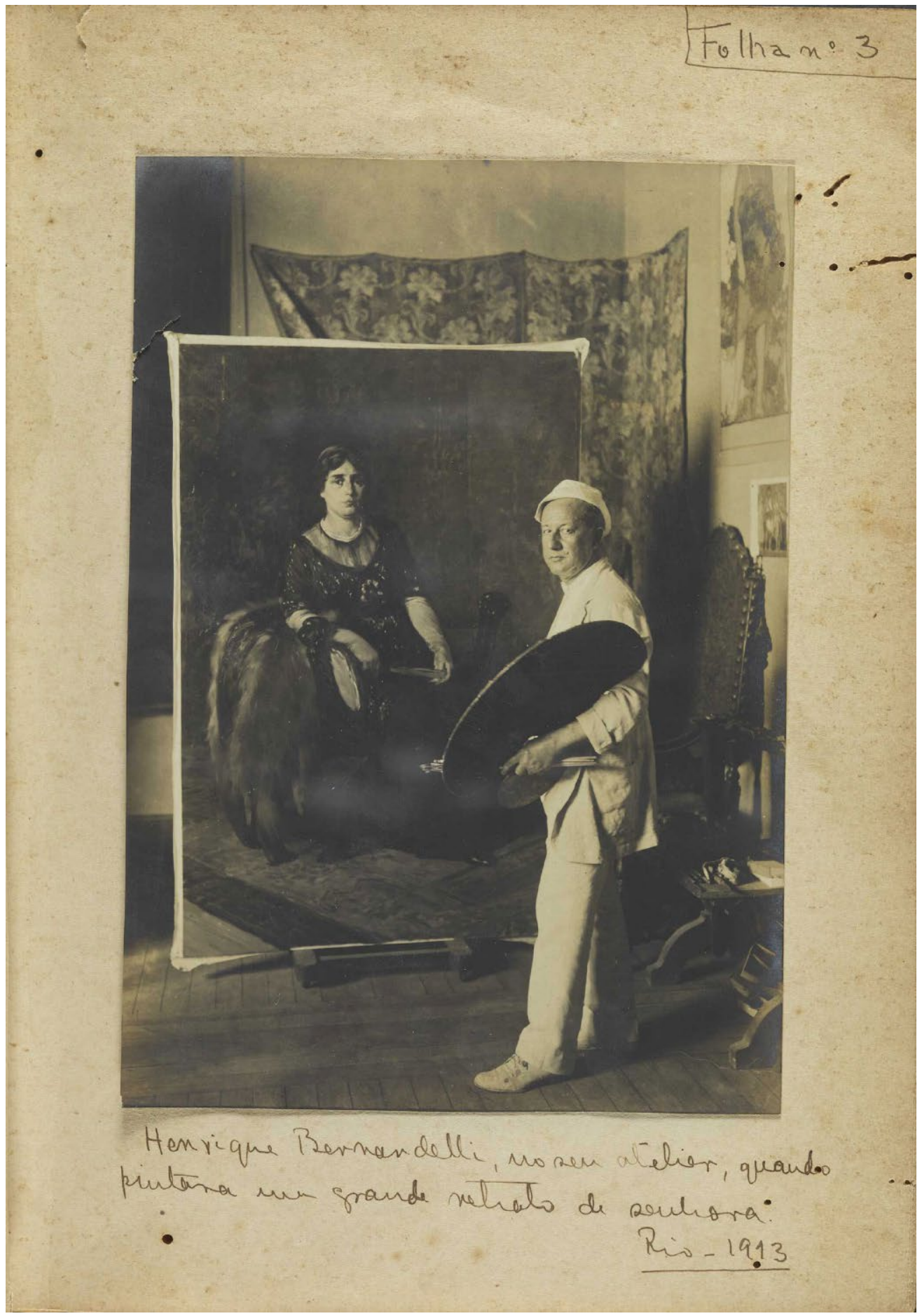

Figura 14 - Henrique Bernardelli, no seu atelier, quando pintava um grande retrato de senhora. Fonte: Henrique... (1913). 


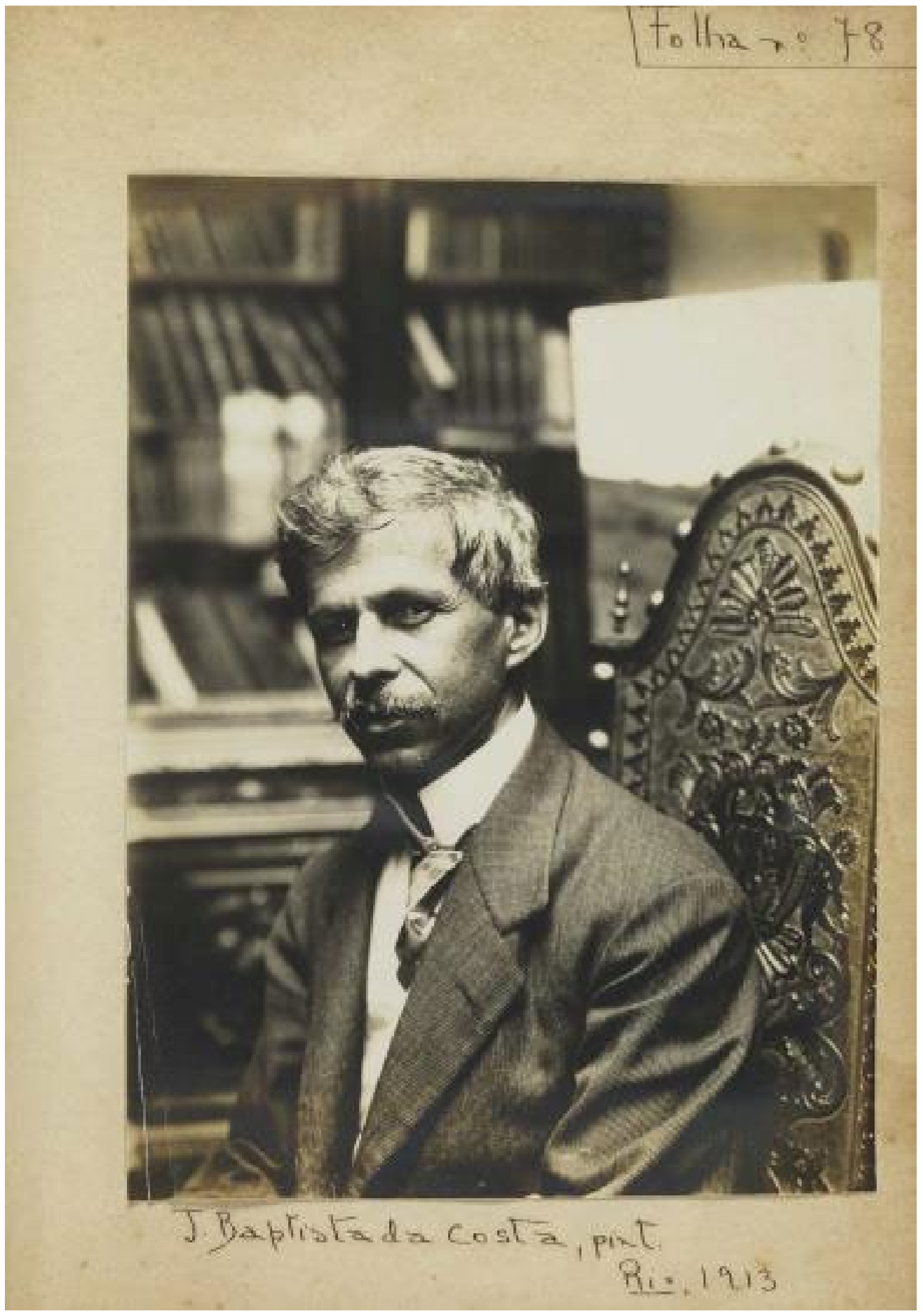

Figura 15 - J. Baptista da Costa, pint. Fonte: J. Baptista... (1913). 
38. Bueno Amador (1918, p. 6). Grifo no original.

39. Octavio Filho (1918, p. 309). Grifo no original.

40. Silva (1926, p. 109). Grifo no original.

41. Informações relativas à vida e obra de Rodolpho Chambelland foram organizadas de acordo com o relato biográfico de Campofiorito (1983, p. 253-258).

\section{O QUADRO DENTRO DO QUADRO: A TELA DE RODOLPHO CHAMBELLAND, SUA REPERCUSSÃO E A ATUAÇÃO DO ARTISTA}

Voltando ao quadro No ateliê, de Arthur Timótheo, e ao Retrato do barão S. de $V$., de Rodolpho Chambelland - o quadro dentro do quadro -, discutimos a repercussão que este último atingiu no período quando foi exposto. Relativo ao Salão de 1918, encontramos uma crítica assinada por Bueno Amador publicada no Jornal do Brasil, de 16 de agosto daquele ano, em que Rodolpho Chambelland é mencionado e também o retrato apresentado nesta edição, mas sem menção ao título:

Rodolpho Chambelland, professor da Escola e, como tal, preso aos deveres do cargo ainda assim consegue fazer-se admirar no 'Salon' com o excellente retrato que apresenta. Senhor absoluto do desenho, que é a maior probidade do artista, na frase de Juglés, senhor absoluto da côr em todos os seus ancenubios, Rodolpho Chambelland passou a tela uma figura viva. A physionomia impregnada de sentimento, 'posa' como tal naturalidade, que o espectador comprehende a serenidade de animo, a serenidade do ambiente e a suave doçura dos contrastes de luz difficillimos de alcançar nesse genero ingrato e que o artista apresenta com todos os característicos de um vencedor consagrado. Admiravel em todos os sentidos, esse trabalho marca mais uma etapa dessa gloriosa jornada de arte que Rodolpho Chambelland traçou para sua vida de artista, na santidade da expressão. ${ }^{38}$

Na matéria "O 'Salão' de 1918" assinada por Rodrigo Octavio Filho para a Revista do Brasil, encontramos menção ao título do retrato exposto pelo pintor e breves elogios: "Rodolpho Chambelland um dos nossos pintores de maior talento, apresenta o magnifico retrato do Barão $S$. de V. muito elegante e sóbrio, onde o talento do artista se manifesta em toda sua pujança". ${ }^{39}$

Por último, em uma passagem encontrada no livro Pequenos estudos sobre arte: pintura esculptura, de Moises Nogueira da Silva, há menção ao título da obra, certificando, assim, que este trataria do retrato do Barão Smith Vasconcellos, a saber: "Rodolpho Chambelland, que mandou o melhor retrato do Salão. O Retrato do Barão de S. de V. é uma obra prima, pela factura, pelo desenho, pelo acabamento, pela intenção, pela vida toda e forte que faz do seu trabalho um sêr, com alma, com vibração". ${ }^{40} \mathrm{~A}$ crítica positiva nos levou a investigar alguns aspectos da trajetória de Rodolpho Chambelland, a fim de identificarmos também a sua aproximação com Arthur Timótheo, seu contemporâneo.

Rodolpho Chambelland ${ }^{41}$ nasceu em 1879, no Rio de Janeiro, irmão mais velho do também pintor Carlos Chambelland (1884-1950). Inicia seus estudos no Liceu de Artes e Ofícios e, em 1901, ingressa no curso livre de pintura na ENBA, 
tendo aulas com Henrique Bernardelli e Rodolfo Amoêdo. Concomitantemente, trabalhou na produção de capas de partituras na Casa Bevilácqua e, posteriormente, retocando fotografias na Casa Bastos Dias. A dedicação aos estudos é recompensada em 1905, quando alcança o Prêmio de Viagem daquele ano com a obra Bacantes em Festa, que permite ao jovem artista viajar para Paris para estudar por dois anos. Em Paris, além de frequentar os salons, museus e ateliês particulares, o pintor teve passagem pela Académie Julien no ano de 1906, tendo como professores Jean-Paul Laurens e Henri Royer. ${ }^{42}$ De volta ao Brasil, expõe, em 1908, no Rio de Janeiro e continua participando das Exposições Gerais com assiduidade e, em 1911, integra o grupo de artistas convidados para decorar o pavilhão do Brasil na Exposição Internacional de Turim, junto ao colega Arthur Timótheo. Em 1916, é nomeado para ocupar a cadeira de desenho de modelo vivo na ENBA, onde permanece até 1946. Rodolpho Chambelland, segundo Campofiorito, "deixou sua obra pouco numerosa, porém de boa representatividade na pintura brasileira. $\bigcirc$ retrato aparece com destaque e são muitas as telas no gênero [... ]". ${ }^{43} \bigcirc$ pintor faleceu no ano de 1967, no Rio de Janeiro.

Rodolpho Chambelland obteve êxito em sua carreira artística e deixou um legado que permanece vivo no acervo de muitas instituições. Para além do apoio da crítica, premiações, encomendas e apreço de seus comitentes, o pintor integrou o grupo de artistas cariocas atuantes no período e manteve-se próximo aos seus contemporâneos, desenvolvendo uma relação de amizade com alguns deles, por exemplo com Arthur Timótheo, evidenciada pela homenagem ao amigo refletida na produção de No ateliê.

\section{A RELAÇÃO DOS IRMÃOS CHAMBELLAND COM ARTHUR TIMÓTHEO DA COSTA}

Rodolpho Chambelland e Arthur Timótheo da Costa estudaram na ENBA e foram agraciados com o prêmio de viagem ao exterior. Arthur Timótheo viajou em 1908, época quando Rodolpho Chambelland retornara ao Brasil. Contudo, seu irmão Carlos Chambelland, ganhador do prêmio de viagem de 1907, partiu também em 1908 para Paris. Cabe destacar que, em 1907, ocorreram duas premiações de viagem. Segundo a repercussão da época acerca do motivo deste ocorrido:

Coube o premio de viagem ao Sr. Carlos Chambelland. O Sr. Eduardo Bevilacqua não se aproveitou do premio de viagem obtido no salão de 1906, e isso por dolorosos motivos.
42. Para a listagem dos artistas homens que passaram pela Académie Julian, conforme os anos e seus professores cf. Simioni (2008, p. 343).

43. Campofiorito (1983, p. 258). 
44. Exposição... (1907). Grifo no original.

45. Chambelland (1909).

46. Boucher (2010).

47. Óleo sobre tela $100 \times 89$ $\mathrm{cm}, \mathrm{c} .1520$. Acervo do $\mathrm{Mu}-$ seu do Louvre, Paris. Disponível em: <https://bit. ly/2GMhgYX>. Acesso em: 10 nov. 2020.

48. Referimo-nos à obra Arranjo em cinza e preto n. 1 , de 1871, parte do acervo do Museu de Orsay, Paris, e a obra Arranjo em cinza e preto n. 2, de 1872-1873, no acervo do Kelvingrove Art Gallery and Museum, Glasgow. Cf. Bittencourt (2015, p. 192-212).

49. Bittencourt (2015).
A inesperada perda de seu pae, obrigou o joven artista a ficar no Rio, succedendo-o na importante casa commercial de respeitável notoriedade. O Director da Escola propoz então, em vista do parecer do Jury e approvação do Conselho Superior de Bellas Artes, que o governo da Republica fizesse recair o pensionato, não aproveitado, no Sr. Arthur Timótheo.

No Salão de 1907, portanto, alcançaram premio de viagem á Europa, com pensão do Estado durante dous annos, os Sis. Chambelland e Arthur Timótheo. ${ }^{44}$

Podemos imaginar, então, que os jovens pintores tenham se aproximado quando ambos cumpriam o período de estudo no exterior e, possivelmente, tenham desenvolvido laços de amizade, visto que em 1909 Carlos Chambelland produz um Retrato do pintor Artur Timoteo da Costa. ${ }^{45}$ Nesse retrato, o artista é representado sem alusão imediata ao ofício, isto é, atributos vinculados à profissão de pintor, como pincéis e paleta em suas mãos, algo comum em outras representações de artistas, estão ausentes. Ele é representado sentado em uma confortável poltrona com as pernas cruzadas, olhando para o observador com seu semblante pensativo sustentado por sua mão esquerda; esta mão é envolta por uma luva e observamos que o pintor usa somente a luva na mão esquerda, segurando o par abaixo do queixo. Vale destacar que as luvas eram comuns na retratística burguesa e remetiam-se ao passado ${ }^{46}$ como podemos observar em Portrait d'homme, dit l'homme au gant (Homem com uma luva), ${ }^{47}$ de Tiziano.

No antebraço esquerdo de Arthur Timótheo da Costa, observamos o cabo reluzente da bengala que se estende em diagonal por seu corpo. Sua vestimenta é elegante, composta totalmente pela tonalidade marrom e acompanhada por chapéu e lustrosos sapatos. No ambiente, vemos ao fundo, no canto direito atrás da poltrona, possivelmente uma porta e, no canto esquerdo, um desenho ou aquarela exposta pendurada na parede em uma altura próxima do chão; a moldura branca ocupa mais espaço que a obra propriamente e, abaixo dela, um reluzente recipiente de prataria semelhante a um vaso encontra-se no chão, talvez um porta-bengalas com alguns pincéis em seu interior - um sinal evidente da profissão do retratado.

A construção desse retrato nos leva às representações dos dândis e a uma série de obras que seguem essa temática. De maneira mais evidente, a obra de James MacNeill Whistler ${ }^{48}$ é explicitamente referenciada nesse retrato. A pesquisadora Renata Bittencourt, em sua tese de doutorado Um dândi negro: o retrato de Arthur Timótheo da Costa de Carlos Chambelland ${ }^{49}$ discute com profundidade esse retrato e investiga o dandismo e suas representações, estabelecendo comparações entre artistas e demais obras que mantem diálogo com o Retrato do pintor Arthur Timótheo, feito por Carlos Chambelland. Não obstante, chamamos atenção ainda para a dedicatória presente no canto esquerdo inferior da obra: "AO AMIGO/TIMOTHEO/ 
LEMBRAN/CCA/ DO CARLOS"; ao lado direito desta vê-se a localização e datação "PARIS/ 1909", ou seja, a obra fora realmente realizada tendo em vista o propósito de presentear o amigo com o retrato. ${ }^{50}$

Para além das obras trabalhadas por Bittencourt, destacamos um retrato exposto por Carlos Chambelland no Salão de 1907, junto ao premiado Final de jogo. ${ }^{51} \bigcirc$ quadro intitulado somente como Retrato na lista de obras expostas ${ }^{52} \mathrm{e}$ também na imagem identificada na revista Renascença de novembro de 1907 (Figura 16), apresenta semelhanças com o Retrato do pintor Arthur Timótheo da Costa, sobretudo no posicionamento do retratado, em sua vestimenta elegante, na presença da luva em somente uma das mãos do retratado, que por sua vez segura seu par, assim como o quadro pendurado em posição baixa na parede. Há ainda a presença de um adorno na cabeça dos retratados mesmo em ambientes internos, pois em um Arthur Timótheo é retratado com um chapéu, enquanto no outro vemos que o homem usa uma espécie de boina ou algum outro elemento que não identificamos com precisão. $O$ homem do Retrato usa em sua mão direita, sem luva, alguns anéis e percebemos que seu braço repousa sobre um livro ou caderno disposto sobre a mesa, o que pode evidenciar também o caráter de erudição do retratado. Este quadro foi apresentado no salão de 1907, portanto antes da viagem de estudos a Paris feita por Chambelland, o que talvez possa indicar que o modelo para o retrato de Arthur Timótheo como dândi já estivesse internalizado pelo pintor, antes mesmo do seu primeiro contato com o exterior.

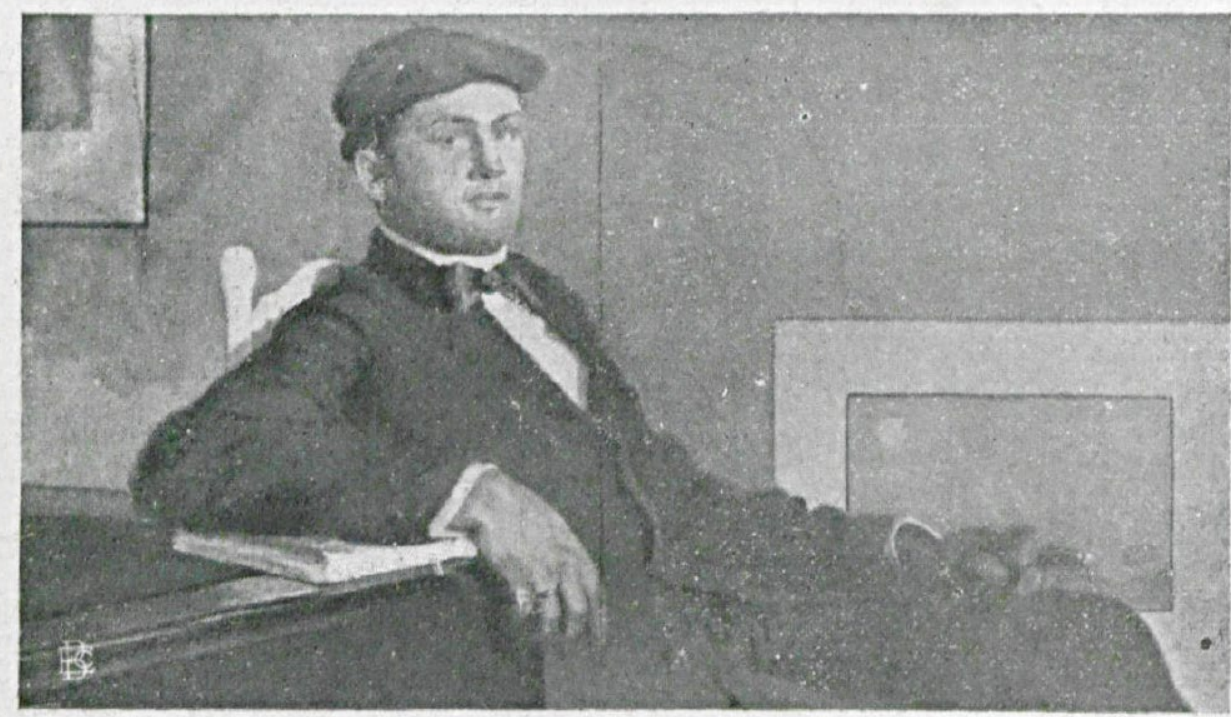

RETRATO - Carlos Chambelland

Figura 16 - Retrato, Carlos Chambelland, s. d. Fonte: Exposição... (1907)
50. Chambelland (1909).

51. Óleo sobre tela, $102 \times 150$ $\mathrm{cm}$. Acervo do Museu Nacional de Belas Artes, Rio de Janeiro. Disponível em: $<$ https://bit.ly/2ImiFpM>. Acesso em: 11 dez. 2018.

52. Levy (2003, p. 247). 
Isto posto, destacamos que a representação do barão de Vasconcellos em seu retrato também remete à temática do dandismo, em sua elegância, no olhar blasé, em sua postura corporal e também na bengala em uma de suas mãos. Ao analisarmos outras obras de Rodolpho Chambelland, também observamos referências à figura do dândi, como no Retrato do Dr. José Marianno Filho (Figura 17) e no Retrato do Dr. João Hermes (Figura 18), ambos expostos na $19^{\circ}$ Exposição Geral de Belas Artes, de 1912,53 e que trazem os retratados sentados em posições semelhantes, com o corpo voltado para a esquerda do quadro, trajando-se muito elegantemente e com chapéus à cabeça. Nesse sentido, Rodolpho Chambelland estaria imerso nessa cultura de referências ao dandismo, já evidenciada por seu irmão, Carlos Chambelland, no retrato de Arthur Timótheo da Costa.

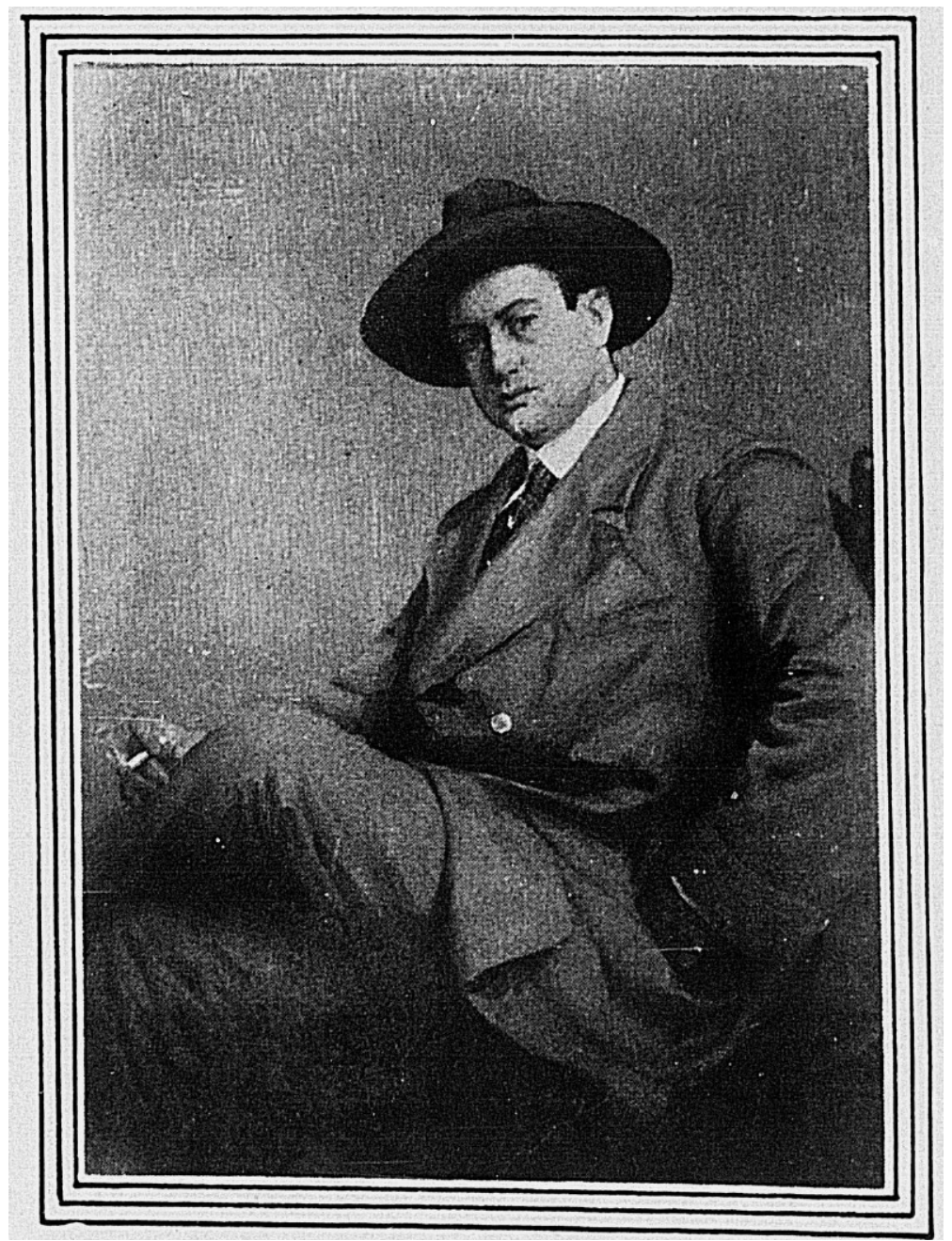

Figura 17 - Retrato do Dr. José Marianno Filho, Rodolpho Chambelland, s. d. Fonte: Cremona (1923, p.22). 


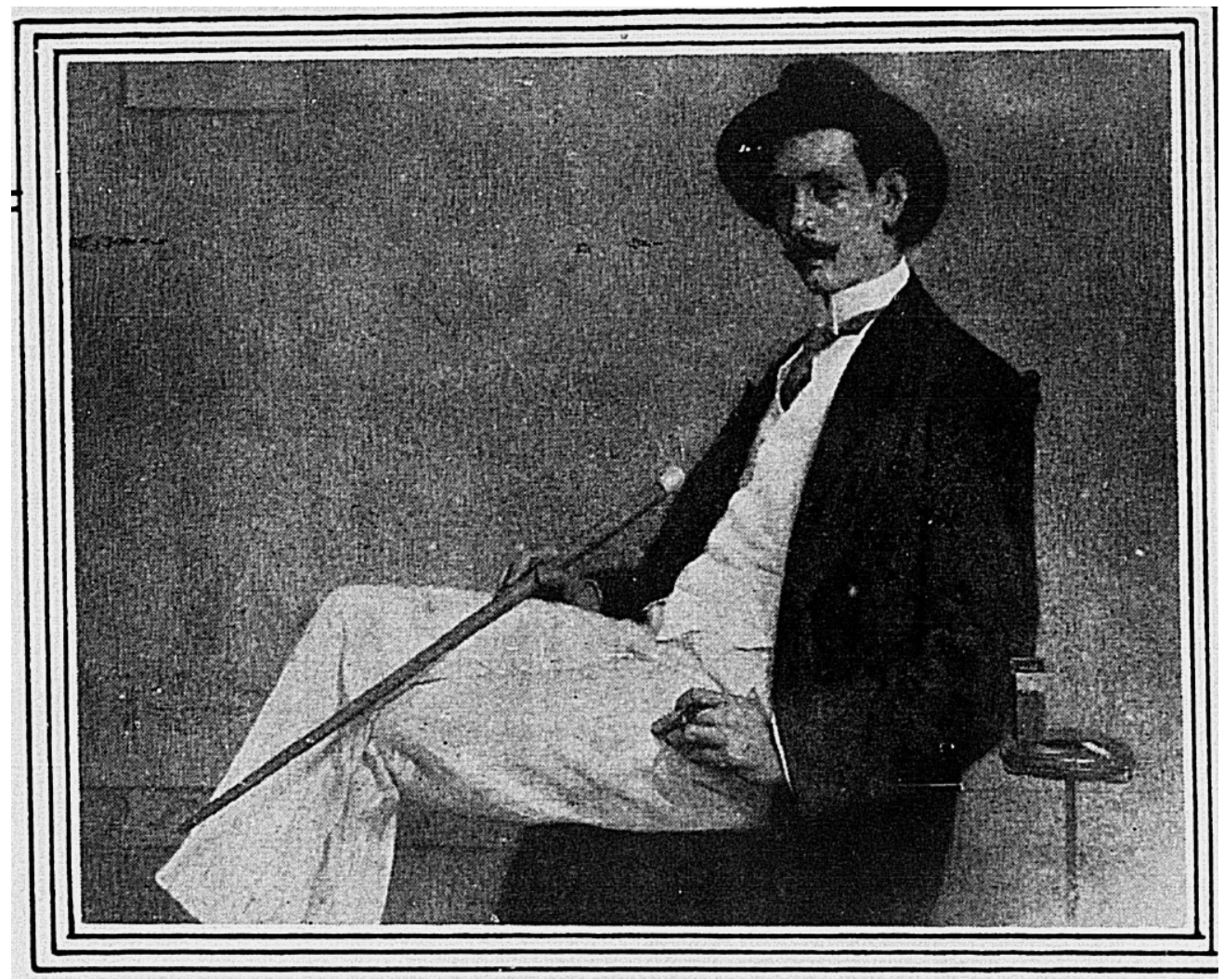

54. A Força... (1916, p. 18). Grifo meu.

Figura 18 - Retrato do Dr. João Hermes, Rodolpho Chambelland, s. d. Fonte: Cremona (1923, p. 22).

Outro ponto a se destacar acerca da relação nutrida entre os irmãos Chambelland e os Timótheo da Costa seria a provável proximidade entre seus ateliês, pois, de acordo com um extrato de notícia localizado na Revista da Semana, de 22 de abril de 1916 :

Há agora um novo subúrbio servido pelos trens da Leopoldina e já bastante povoado. Desse novo subúrbio a capital é Ramos, onde no alto de um morro alguns dos nossos pintores e esculptores como Correia Lima, os irmãos Timótheo e os irmãos Chambelland edificaram ateliers-habitações á maneira de Dusseldorf. ${ }^{54}$

Talvez essa menção aponte indícios para pensarmos que em 1918 - ano em que Rodolpho Chambelland produz o retrato do Barão S. Vasconcellos, assim como Arthur Timótheo pinta No ateliê - os ateliês de ambos continuavam próximos. Nesta perspectiva, talvez Arthur Timótheo tenha acompanhado a realização do retrato do Barão de Vasconcellos e tenha traçado os esboços de No ateliê nesta ocasião. Algo 
55. Óleo sobre tela, $63,7 \times 53,5 \mathrm{~cm}$, c. 1913 . Acervo do Museu Metropolitano de Nova York, Nova York. Disponível em: $<$ https://bit. ly/3kgGJaz>. Acesso em: 10 nov. 2020.

56. Óleo sobre tela, $91,4 \times 72,4 \mathrm{~cm}, 1910$. Paradeiro desconhecido. Disponível em: <https://bit. ly/3nafAYT>. Acesso em: 10 nov. 2020.

57. Levy (2003, p. 470).

58. Levy (2003, p. 481).

59. Pederneiras (1918, p. 18).

60. Silva (1926, p. 110). semelhante deve ter ocorrido em Lovis Kronberg in his studio in Copley Hall (Louis Kronberg em seu ateliê em Copley Hall), ${ }^{55}$ de Goodwin Arthur Clifton. Neste ateliê, observamos no primeiro plano um artista pintando no canto esquerdo inferior da tela; ele é retratado sentado e tem as costas voltadas para o observador, devido ao recorte da tela só enxergamos meio corpo do artista que olha para o cavalete à sua frente. Ao fundo, uma mulher é retratada sentada em uma cadeira com a cabeça baixa compenetrada na costura; e no espelho, no canto superior esquerdo da tela, podemos perceber o reflexo de dois homens próximos a um cavalete, um está abaixado e outro ereto, sendo eles respectivamente o reflexo do pintor Lovis Kronberg e o responsável pelo quadro Goodwin Arthur Clifton. Contudo, nos interessa destacar que neste quadro existe menção à obra Mending ballet skirts (Remendando saias de ballet), ${ }^{56}$ de Louis Kronberg, relação até então inédita nas análises das obras. Nesse sentido, semelhante ao que ocorre em No ateliê, temos a menção ao momento em que o pintor está trabalhando e produzindo uma obra que de fato existiu.

Apontamos ainda que, no ano de 1918, quando No ateliê foi produzida, Arthur Timótheo exibiu duas obras na Exposição Geral de Belas Artes que, conforme a transcrição do catálogo de Levy, seriam: "Retratando (têmpera)" e "Paisagem (têmpera)". 57 Até o momento, desconhecemos o paradeiro da obra intitulada "Retratando" e cogitamos que ela pudesse fazer referência a No ateliê, mas devido às diferentes técnicas - têmpera e óleo sobre tela - descartamos a hipótese. Contudo, é notável que, no mesmo ano, Arthur Timótheo expôs uma obra no salão com este título e talvez exista a possibilidade de ambas manterem alguma relação, no sentido da composição ou até mesmo do tema, já que o título "Retratando" nos leva a pensar em uma obra onde veríamos um pintor retratando alguém que também estaria no mesmo recinto, como ocorre em No ateliê. Entretanto, seu irmão, João Timótheo da Costa, participou da Exposição Geral de 1918 expondo um quadro intitulado "No ateliê", 58 também desconhecido por nós e somente identificado através de uma caricatura publicada na Revista da Semana, de 31 de agosto de 1918, referente ao "O Salão Cômico", de autoria de Raul Pederneiras. Abaixo deste desenho, lê-se: "J. Timótheo. Pintor que pinta um pintor pintando um pintor"59 e, ao que parece, a tela foi apreciada pela crítica, como podemos perceber na menção de Moises Nogueira da Silva ainda sobre O Salão Nacional de 1918:

Finalmente, não por ser o último, mas por simples disposição numérica, vem João Timótheo da Costa, que se apresenta o mais francês dos nossos artistas. O seu quadro No atelier causaria admiração mesmo entre os trabalhos dos mais distinctos pintores da França moderna. E' um encanto. 60 
Nesse sentido, João Timótheo apresentou um quadro que certamente contribuiria muito para a nossa análise, por se tratar de uma obra em que representaria a temática de um pintor retratando o outro no ateliê, sendo ela apresentada ao público no mesmo ano em que fora produzida a obra de Arthur Timótheo, mas infelizmente desconhecemos demais informações sobre a obra.

\section{NO ATELIÊ EM DIÁLOGO COM OUTRAS OBRAS: A TEMÁTICA DA REPRESENTAÇÃO DO ARTISTA E DE SEU AMBIENTE DE TRABALHO}

No que diz respeito à circulação de No ateliê, antes de sua chegada ao acervo da Pinacoteca do Estado de São Paulo, temos pouquíssimas informações sobre ela. A obra é identificada em imagens presentes em periódico da época, relativas ao ateliê de Arthur Timótheo da Costa (Figura 19), em que vemos parte da tela na imagem inferior, no canto esquerdo. Também identificamos a obra em imagens correspondentes ao ateliê de João Timótheo da Costa, irmão mais velho de Arthur Timótheo da Costa, como ocorre na imagem do $\bigcirc$ Jornal, de 5 de setembro de 1926 (Figura 20), em que a observamos atrás do pintor, no canto esquerdo da imagem e também na imagem vinculada na Illustração Brasileira, de junho do mesmo ano (Figura 21 ), no canto direito do registro fotográfico. Os irmãos dividiam o ateliê e é totalmente justificável que, após a morte de Arthur, João tenha continuado com suas obras no ateliê, identificáveis em algumas fotografias, mas demais informações sobre a circulação da tela ainda carecem de verificação.

A descrição desta obra está presente no catálogo Arte no Brasil: uma história na Pinacoteca de São Paulo, em que o pintor Arthur Timótheo da Costa é abordado:

Negro e de origem humilde, ao longo de sua carreira Arthur Timótheo da Costa executou inúmeros autorretratos e representações do interior de seu ateliê e de ateliês de outros artistas. Foi um dos pintores ocidentais que tomaram o estúdio e suas convenções como ponto de partida para compreender o mundo. Apesar de também ter trabalhado ao ar livre e de ter produzido grande número de paisagens, a relação de Timótheo da Costa com a realidade deu-se primariamente por meio do espaço destilador do estúdio. ${ }^{61}$

Essa noção de compreensão do mundo através do ateliê é certamente algo poético que se adequa aos questionamentos sobre o ambiente do ateliê como espaço de trabalho, afirmação e sociabilidade, sendo que existem outros aspectos que necessitam ser aprofundados. Nesse sentido, Alain Bonnet, em seu artigo, 
62. Bonnet (2018, p. 177)

63. Idem (2012, p. 11), tradução nossa. presente no catálogo da exposição Trabalho de artista: imagem e autoimagem (1826-1929), encerra sua narrativa afirmando que: "o ateliê exerceu, e talvez ainda exerça, um profundo fascínio baseado tanto na sedução romântica da vida do artista, na qual despreocupação e alegria convivem com a miséria e o desespero, quanto no mistério do local de criação". ${ }^{62}$ Ainda conforme o autor, em L'Artiste en representation. Image des artistes dans l'art du XIXe Siècle,

A transformação do artista em uma personalidade pública aumentou ainda mais o desejo de penetrar no próprio lugar da criação, um lugar cheio de segredos, um lugar imbuído de uma atmosfera quase mágica, um lugar que poderia, assim como o autorretrato, refletir a personalidade de seu ocupante e explicar a natureza de suas produções. ${ }^{63}$

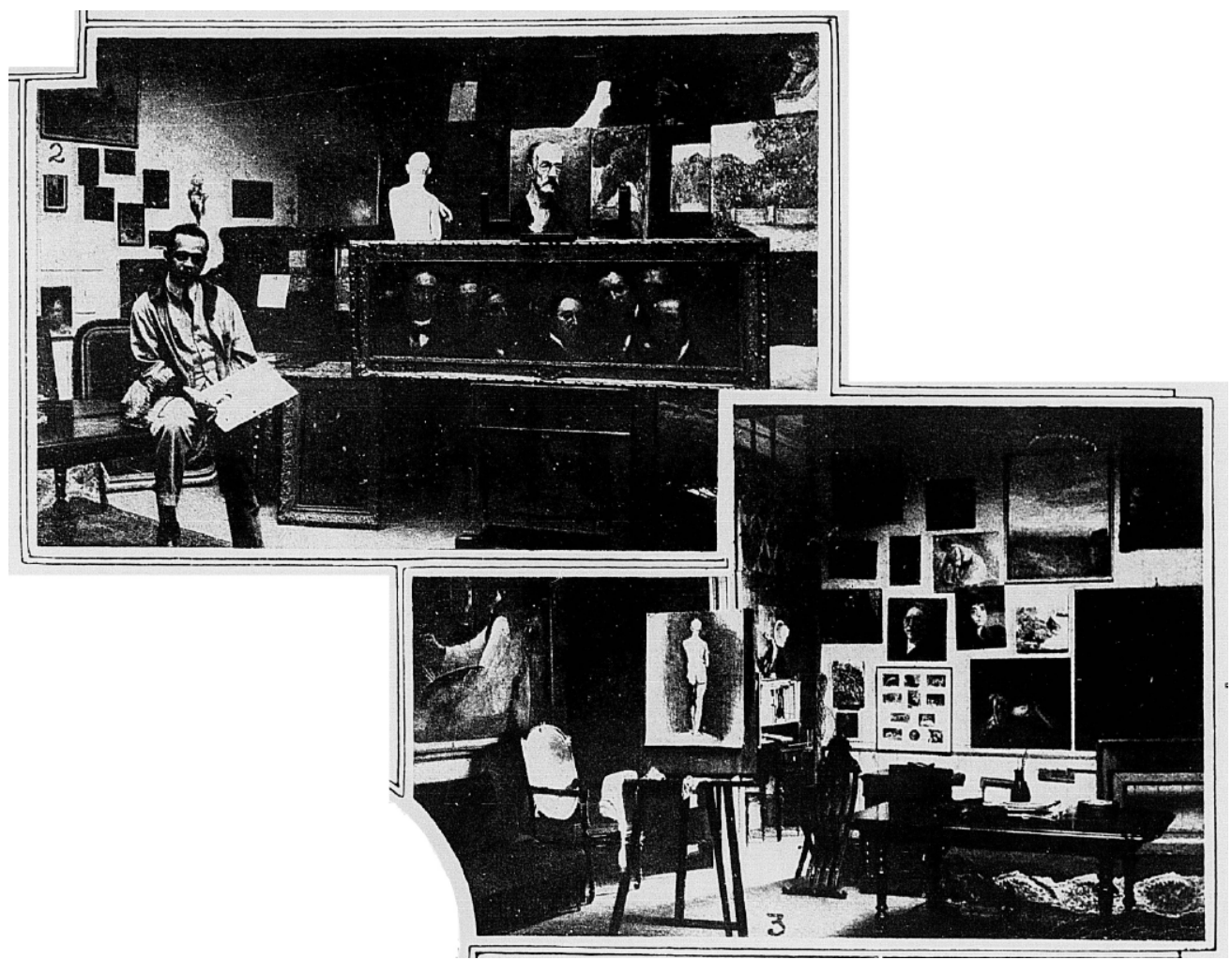

Figura 19 - Arthur Timotheo (acima) e Um aspecto do atelier (abaixo). Fonte: Mattos (1921, p. 50). 


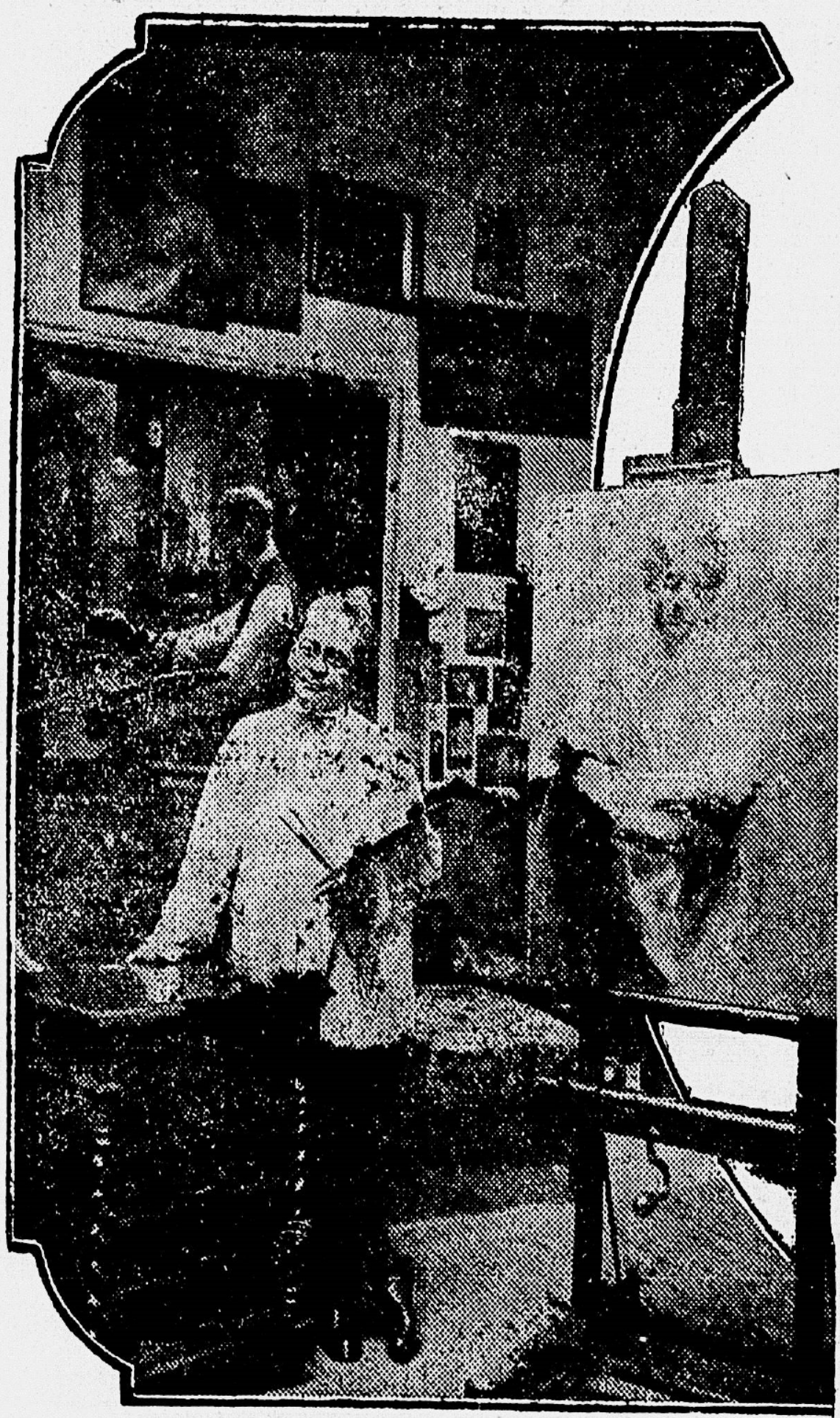

Joăo Tìmoteo junto a $\mathrm{nm}$ dos quadros que está nltimando $\mathrm{cm}$ seu at cller
Figura 20 - João Timoteo junto a um dos quadros que está ultimando em seu atelier. Fonte: $\mathrm{Na}$ intimidade... (1926, p. 17). 


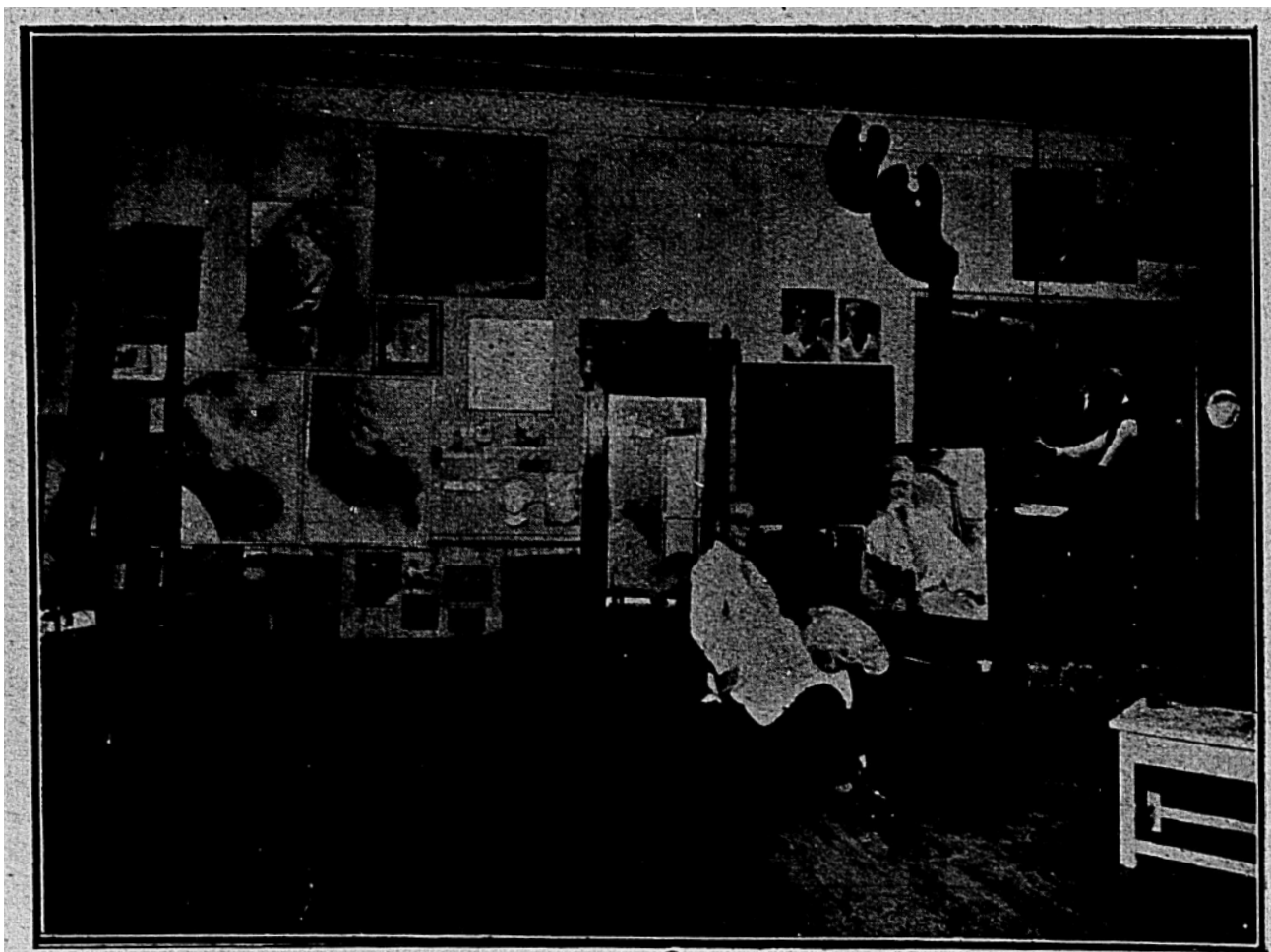

\section{O artista trabalhando.}

Figura 21 - $\bigcirc$ artista trabalhando. Fonte: Entre... (1926, p. 27).

À vista disto, é evidente a importância do ateliê e as representações deste espaço na carreira artística de Arthur Timótheo da Costa não são isoladas da produção de outros artistas que por vezes se voltaram ao tema, a fim de se autorrepresentar, homenagear algum colega artista ou produzir uma obra vinculada à temática de gênero - em que o ateliê também aparece de maneira representativa e com muitos significados -, como foi o caso de Almeida Júnior (1850-1899). Fernanda Pitta elucida que, para o artista ituano,

ateliê é tema privilegiado para a construção de sua persona de artista moderno, aquele que reivindica autonomia, originalidade, individualidade no trabalho artístico, mas que também precisa dar provas de competência, de conhecimento da tradição, de erudição e seriedade - além de flertar, na medida 'certa', com o gosto do público e com a moda. ${ }^{64}$ 
Talvez Arthur Timótheo concebesse de forma semelhante suas representações de ateliês, o que justificaria as várias obras do gênero ao longo de toda sua produção artística. Dentre elas, temos algumas obras produzidas em seu período de estudo em Paris, como a obra No atelier (Figura 22) presente na revista Illustração Brasileira, de novembro de 1921. Nesta obra, vemos o pintor em pé pintando uma tela em um cavalete no canto esquerdo, na sua frente está uma modelo nua com o corpo inclinado. No ambiente observamos poucos móveis, o aquecedor e um banco onde está disposto um busto feminino.

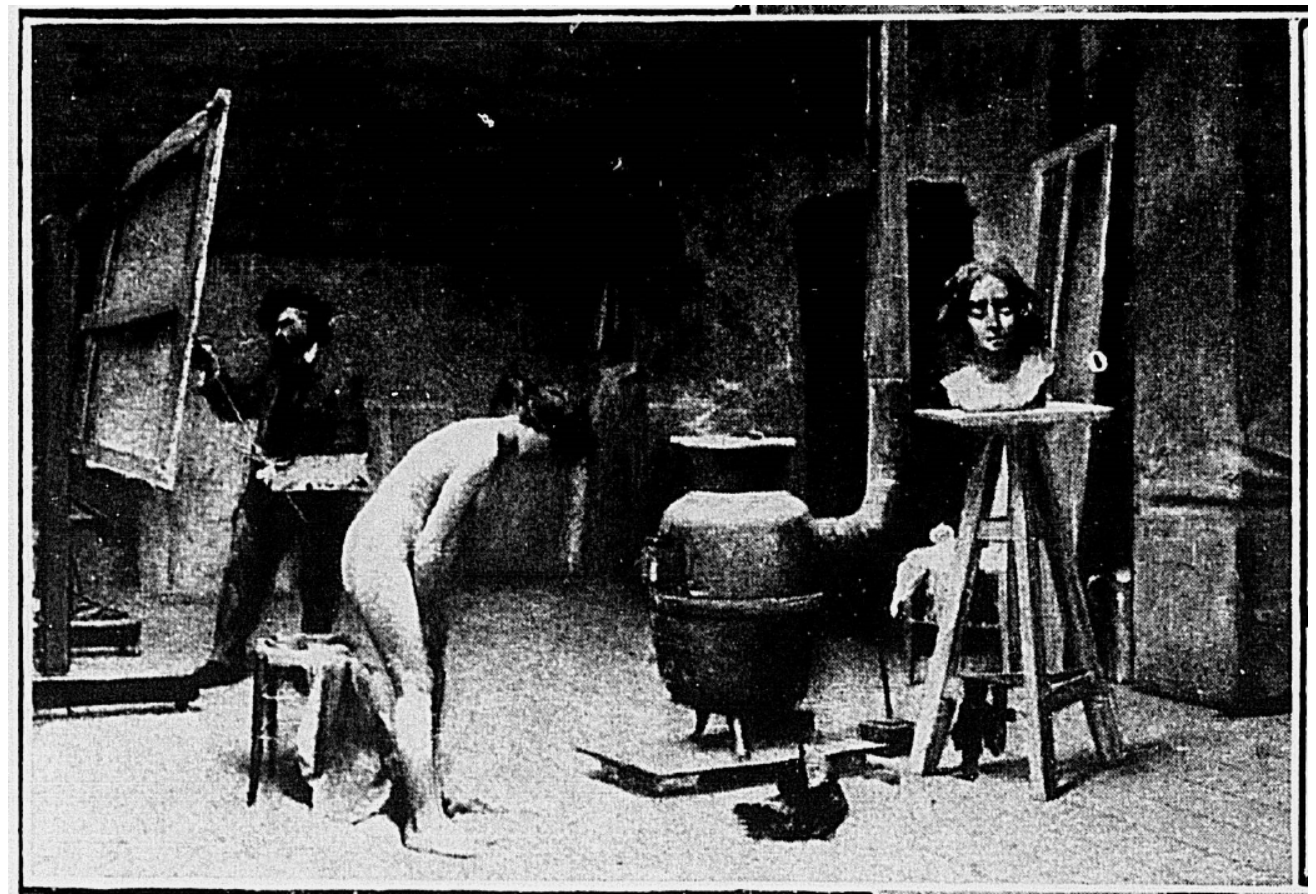

Figura 22 - No atelier, Arthur Timótheo da Costa. Fonte: Mattos (1921, p. 51 ).

Em seu período em Paris, Arthur Timótheo também produziu Ateliê, ${ }^{65}$ No Atelier de Lucílio, ${ }^{66}$ Retrato do Escultor Eduardo Sá, ${ }^{67}$ Pintor no Atelier, Paris, França ${ }^{68}$ e, possivelmente, outras obras do gênero que desconhecemos. Por certo, sua vivência no exterior deve ter aflorado seu interesse pelo ateliê e pela representação do artista em seu espaço de trabalho. No entanto, antes de sua viagem temos a obra Sem título, 69 de 1907, que também representa um ateliê e recorre à temática infantil, pois observamos um menino deitado no chão de madeira, com pincéis e paleta, empenhado na produção de um desenho à sua frente. $\bigcirc$ menino reproduz a imagem do boneco de madeira localizado no canto direito do quadro, o modelo para o precoce artista, que descarta as brincadeiras infantis, visto a bola solitária
65. Óleo sobre tela, $54,2 \times 64$ cm, 1908. Paradeiro desconhecido. Disponível em: <https://bit.ly/3pksGEY>. Acesso em: 11 nov. 2020.

66. Óleo sobre tela $22,0 \times 38,0 \mathrm{~cm}, 1910$. Acervo do Museu Antônio Parreiras, Niterói. Disponível em: $<$ https://bit.ly/2JV9oFL $>$ Acesso em: 11 nov. 2020.

67. Óleo sobre tela, $176,0 \times 106,0 \mathrm{~cm}, 1910$. Acervo do Museu Nacional de Belas Artes, Rio de Janeiro. Disponível em: <https:// bit.ly/3neQtEd>. Acesso em: 11 nov. 2020. Para análise desta tela, cf. Aquino Gomes (2018).

68. Óleo sobre tela, $36,0 \times 55,3 \mathrm{~cm}, 1910$. Coleção de Sergio Sahione Fadel. Disponível em: <https://bit.1y/2ImycWt> Acesso em: 11 nov. 2020.

69. Óleo sobre tela, $120,0 \times 80,0 \mathrm{~cm}, 1907$. Coleção Pinakotheke de Max Perlingeiro. Disponível em: <https://bit.ly/3knlqV4>. Acesso em 11 nov. 2020. 
70. Óleo sobre tela, $76,5 \times 64,5 \mathrm{~cm}, 1741$. Acervo do Museu de Arte de São Paulo Assis Chateaubriand, São Paulo. Disponível em: $<$ https://bit.ly/3pmJf2M>. Acesso em: 11 nov. 2020.

71. Óleo sobre tela, $65,0 \times 54$ $\mathrm{cm}, 1910$. Paradeiro desconhecido. Disponível em: $<$ https://bit.ly/38yy811>. Acesso em: 11 nov. 2020.

72. Óleo sobre tela, $43,5 \times 58,0 \mathrm{~cm}, \mathrm{~s}$. d. Acervo do Museu Nacional de Belas Artes, Rio de Janeiro. Disponível em: $<$ https://bit. 1y/32zLohY>. Acesso em: 11 nov. 2020.

73. Óleo sobre tela, 1940. Acervo do Museu Antonio Parreiras, Niterói. Disponível em: <https://bit. ly/38zsATG $>$. Acesso em: 11 nov. 2020.

74. Cavalcanti (2018, p. 55).

75. Óleo sobre tela, $45,5 \times 170,6 \mathrm{~cm}, 1921$. Acervo do Museu Nacional de Belas Artes, Rio de Janeiro. Disponível em: $<$ https://bit. ly/2IiAmqE >. Acesso em: 11 nov. 2020. no canto direito inferior, à maneira de Jeune ecolier qui jove au toton (Retrato de Auguste Gabriel Godefroy), ${ }^{70}$ de Jean-Baptiste-Siméon Chardin, em que o menino deixa os livros para brincar com o peão. Contudo, no caso da obra de Arthur Timótheo, temos um reforço da identidade do artista já na infância.

Em outras obras de Arthur Timótheo da Costa, os atributos do ofício de um pintor também estão presentes, como em Ziza no ateliể e na Modelo em repouso, ${ }^{72}$ que apresentam mulheres em contextos distintos. A primeira aparece compenetrada lendo um livro com os pés descalços, enquanto a segunda, uma modelo, é representada nua - mas com sandálias em seus pés -, sentada relaxadamente em uma poltrona com semblante pensativo, tendo em suas mãos paleta e pincéis, isto é, duas formas de representações da figura feminina: uma priorizando a questão intelectual e a outra explorando a sexualidade do corpo feminino exposto. A modelo nua no ateliê parece incorporar uma alegoria à pintura, ou como se assumisse o lugar do artista ao ser representada neste espaço e com os utensílios do ofício em mãos.

Com efeito, a representação do espaço do ateliê, de seus utensílios e a dinâmica do ofício realizado nesse ambiente eram temas caros a Arthur Timótheo e, corriqueiramente, apareceram em sua produção. Suas obras demonstram o gosto pela temática e sua versatilidade para evocar o assunto, usufruindo de técnicas e diversificando as pinceladas em suas composições.

\section{CONSIDERAÇÕES FINAIS}

Arthur Timótheo abordou o tema do ateliê diversas vezes, autorretratando-se ou homenageando colegas de ofício. Já Rodolpho Chambelland não seguiu este caminho e até mesmo quando retratou outro pintor em Antônio Parreiras ${ }^{73}$ não inseriu no retrato os atributos do ofício ou menções às pinturas históricas, aos nus ou às paisagens que tanto consagraram Antônio Parreiras e que, de acordo com Ana M. T. Cavalcanti, eram "sinais de sua versatilidade e capacidade de realizar diversos gêneros". ${ }^{74}$ Chambelland optou por retratá-lo como civil, em meio corpo, em um fundo neutro que destaca a vestimenta branca de Parreiras e seus cabelos grisalhos.

Arthur Timótheo da Costa foi, certamente, um dos mestres na arte da representação do artista no ateliê. Cabe ainda mencionar que a representação de Rodolpho Chambelland no quadro No ateliê não foi isolada, pois ele também aparece entre os bustos representados em Alguns colegas: sala de professores. ${ }^{75}$ Ao isolarmos sua figura, percebemos certa semelhança com uma fotografia datada 
de 1913. ${ }^{76}$ Nesta perspectiva, interessa-nos apontar que o artista também se insere neste retrato em grupo, realizando mais um de seus autorretratos. ${ }^{77}$

Arthur Timótheo renovou, assim, seu interesse pela sua própria imagem, pela imagem de artistas contemporâneos a ele e ainda pelo espaço do ateliê do artista. No ateliê evidencia sua própria fatura em associação ao do colega Rodolpho Chambelland, eleva sua profissão e de seus pares, acentua a importância das encomendas e o caráter social e afirmativo do retrato na sociedade carioca. Em um momento de tantas incertezas e debates sobre a história dos negros no Brasil e no mundo, é fundamental trazer à tona a importância de Arthur Timótheo da Costa e sua reflexão artística no retrato triplo No Ateliê.
76. Cf. Chambelland (1913).

77. São três autorretratos conhecidos de Arthur Timótheo da Costa, a saber: Autorretrato. Óleo sobre tela, $41,0 \times 33,0 \mathrm{~cm}, 1908$. Acervo da Pinacoteca do Estado de São Paulo, São Paulo. Autorretrato. Óleo sobre tela, $86,1 \times 79,0 \mathrm{~cm}, 1919$. Acervo do Museu Nacional de Belas Artes, Rio de Janeiro. Autorretrato. Óleo sobre tela, dimensões não especificadas, s. d. Acervo do Museu Afro Brasil, São Paulo. Para a análise dos autorretratos de Arthur Timótheo da Costa cf. Bittencourt (2015, p. 20-41) e Amancio (2016, p. 131-141). 


\section{REFERÊNCIAS}

FONTES IMPRESSAS

A FORÇA do genio. Revista da Semana, Rio de Janeiro, ano 17, n. 11, 22 abr. 1916, p. 18. Disponível em: <https://bit.ly/3eHo2f3> . Acesso em: 9 nov. 2020.

ALBUQUERQUE, Lucílio de. Retrato de Gerogina. 1920. 1 original de arte, óleo sobre tela, 145,5×96,0 cm. Coleção do Museu de História e Artes do Estado do Rio de Janeiro, Niterói.

AMADOR, Bueno. Belas-Artes. Jornal do Brasil, Rio de Janeiro, 16 ago. 1918. p. 6, col. 6.

ARESTIZÁBAL, Irma; GRINBERG, Piedade Espstein. Antônio Virzi. Arquitetura Revista, Rio de Janeiro, v. 7, p. 4-27, 1989.

CATALOGO illustrado da exposic?a?o retrospectiva de arte ornamental portugueza e hespanhola celebrada em Lisboa em 1882. Lisboa: Imprensa Nacional, 1882. Disponível em: <https://bit.ly/3mZPXdg>. Acesso em: 9 nov. 2020.

CHAMBELlAND, Carlos. Retrato do pintor Artur Timóteo da Costa. 1909. 1 original de arte, óleo sobre tela, $74 \times 102 \mathrm{~cm}$. Coleção do Museu Nacional de Belas Artes, Rio de Janeiro. Disponível em: <https://bit.ly/38tzN7Z>. Acesso em: 10 nov. 2020.

CHAMBELLAND, Rodolpho, pint. 1913. 1 foto, cópia fotográfica de gelatina e prata, p\&b, 15,6×11,9 cm em folha: 21,7×14,5cm. Disponível em: <https://bit.ly/3eMm3X2>. Acesso em: 11 nov. 2020.

COSTA, Arthur Timótheo da. No ateliê. 1918. 1 original de arte, óleo sobre tela, $195 \times 158 \mathrm{~cm}$. Coleção da Pinacoteca do Estado de São Paulo, São Paulo.

CREMONA, Ercole. Atelier Rodolpho Chambelland. Illustração Brasileira, Rio de Janeiro, $\mathrm{n}$. 35, p. 20-22, 1923. Disponível em: <https://bit.ly/2JR3bKZ>. Acesso em: 10 nov. 2020.

ENTRE artistas. Illustração Brasileira, Rio de Janeiro, ano 7, n. 70, p. 26-29, 1926. Disponível em: <https://bit.ly/32vTaJG>. Acesso em: 11 nov. 2020.

EXPOSIÇÃO de 1907. Renascença, Rio de Janeiro, n. 45, p. 36, 1907. 
FICHA catalográfica da obra (PINA05173), extraída da base de dados da Pinacoteca do Estado, InPatrimonium.net. Documentação do Núcleo de Acervo Museológico - Pinacoteca do Estado de São Paulo.

HENRIQUE Bernardelli, no seu atelier, quando pintava um grande retrato de senhora. 1913. 1 foto, cópia fotográfica de gelatina e prata, p\&b, 15,1×10,8 cm em folha: $21,7 \times 14,5 \mathrm{~cm}$. Coleção da Biblioteca Nacional. Disponível em: <https://bit.ly/32xLUNw>. Acesso em: 10 nov. 2020.

J. BAPTISTA da Costa, pint. 1913. 1 foto, cópia fotográfica de gelatina e prata, p\&b, 16,5×12,2 cm em folha: 21,7×14,5 cm. Disponível em: <https://bit.ly/38uZbKA>. Acesso em: 10 nov. 2020.

MATTOS, Adalberto. Os nossos artistas e os seus ateliers. Illustração Brasileira, Rio de Janeiro, n. 15, p. 50-51, 1921. Disponível em: <https://bit.ly/3neKi2X>. Acesso em: 11 nov. 2020.

NA INTIMIDADE dos nossos artistas. O Jornal, Rio de Janeiro, 5 set. 1926, seção 2, p. 17. Disponível em: <https://bit.ly/35iXs90>. Acesso em: 11 nov. 2020.

OCTAVIO FILHO, Rodrigo. O 'Salão' de 1918. Revista do Brasil, São Paulo, ano 3, v. 9, n. 35, p. 309, 1918. Disponível em: <https://bit.ly/32oM2Pe>. Acesso em: 9 nov. 2020.

PEDERNEIRAS, Raul. Bellas Artes: a exposição de 1918 o salão comico (segunda porção). Revista da Semana, Rio de Janeiro, ano 19, n. 30, 31 ago. de 1918, p. 18. Disponível em: <https://bit.ly/3kfofrc>. Acesso em: 9 nov. 2020.

VASCONCELLOS, Rodolpho Smith de; VASCONCELLOS, Jayme Smith de (orgs.). Archivo nobiliarchico brasileiro. Lausanne: Imprimerie La Concorde, 1918. Disponível em: <https:// bit.ly/2IbQmux>. Acesso em: 9 nov. 2020.

VASCONCELLOS, Jayme Smith de; BRAGANÇA, Luiz de Oliveira. Heráldica Brasileira. Brasil Illustrado, Rio de Janeiro, n. 1, p. 11, 1919. Disponível em: <https://bit.ly/3kf36gF>. Acesso em: 10 nov. 2020.

VIVENDAS pitorescas. A Cigarra, São Paulo, ano 4, n. 66, p. 27-30, 1917. Disponível em: <https://bit.ly/36rqouQ>. Acesso em: 10 nov. 2020.

LIVROS, ARTIGOS E TESES

AMANCIO, Kleber Antonio de Oliveira. Reflexões sobre a pintura de Artbur Timótheo da Costa. 2016. Tese (Doutorado em História Social) - Universidade de São Paulo, São Paulo. 2016. 
AQUINO GOMES, Natália Cristina de. Homenagem ao escultor em seu ateliê: crítica e defesa no retrato de Eduardo de Sá. In: PITTA, Fernanda; BONNET, Alain (orgs.). Trabalbo de artista: imagem e autoimagem (1826-1929). São Paulo: Pinacoteca de São Paulo, 2018. p. 219-237.

AQUINO GOMES, Natália Cristina de. Retrato de artista no ateliê: a representação de pintores e escultores pelos pincéis de seus contemporâneos no Brasil (1878-1919). 2019. Dissertação (Mestrado em História da Arte) - Universidade Federal de São Paulo, Guarulhos, 2019.

ARAUJO, Emanuel (org.). João e Artbur Timotheo da Costa. Os dois irmãos pré-modernistas brasileiros. São Paulo: Museu Afro Brasil, 2012. Catálogo de exposição.

AYERBE, Júlia Souza; HANNUD, Giancarlo; PICCOLI, Valéria (coords.). Arte no Brasil: uma história na Pinacoteca de São Paulo. São Paulo: Pinacoteca do Estado, 2011.

BITTENCOURT, Renata. Um dândi negro: o retrato de Arthur Timótheo da Costa de Carlos Chambelland. 2015. Tese (Doutorado em História) - Universidade Estadual de Campinas, Campinas, 2015.

BONNET, Alain (org.). L'Artiste en representation. Image des artistes dans l'art du XIXe Siècle. Lyon: Fage Éditions, 2012.

BONNET, Alain. O ateliê do artista: do comércio à reclusão. In: PITTA, Fernanda; BONNET, Alain (orgs.). Trabalho de artista: imagem e autoimagem (1826-1929). São Paulo: Pinacoteca de São Paulo, 2018. p. 167-177.

BORGES, Adélia (org.). Coleção Museu da Casa Brasileira. São Paulo: Museu da Casa Brasileira, 2007.

BOUCHER, François. História do vestuário no ocidente. Tradução André Telles. São Paulo: Cosac Naify, 2010.

CAMPOFIORITO, Quirino. História da pintura brasileira no século XIX. Rio de Janeiro: Pinakotheke, 1983.

CAVAlCANTI, Ana Maria Tavares. A imagem do artista: os casos de Antonio Parreiras e Eliseu Visconti. In: PITTA, Fernanda; BONNET, Alain (orgs.). Trabalbo de artista: imagem e autoimagem (1826-1929). São Paulo: Pinacoteca de São Paulo, 2018. p. 51-57.

CHASTEL, André. Fables, formes, figures. Paris: Flammarion, 2000. 2 v. 
FOUCAULT, Michel. As Meninas. In: FOUCAULT, Michel. As palavras e as coisas: uma arqueologia das ciências humanas. Tradução Salma Tannus Muchail. São Paulo: Martins Fontes, 2000.

LEITE, José Roberto Teixeira. Dicionário crítico da pintura no Brasil. Rio de Janeiro: Artlivre, 1988.

LEVY, Carlos Roberto Maciel. Período republicano: catálogo de artistas e obras entre 1890 e 1933. v. 2. Rio de Janeiro: ArteData, 2003.

MALTA, Marize. Olhar decorativo: ambientes domésticos em fins do século XIX no Rio de Janeiro. Rio de Janeiro: Mauad X; FAPERJ, 2011.

MARTIN-FUGIER, Anne. La vie d'artiste au XIXe siècle. Paris: L. Audibert, 2007.

PETER, Lucy. The artistic at work. In: REYNOLDS, Anna; PETER, Lucy; CLAYTON, Martin. Portrait of the artist. Londres: Royal Collection Trust, 2016.

PITTA, Fernanda; BONNET, Alain (orgs.). Trabalbo de artista: imagem e autoimagem (18261929). São Paulo: Pinacoteca de São Paulo, 2018.

PITTA, Fernanda Mendonça. O jabuti e a paleta: o ateliê e o artista em Almeida Júnior. Concinnitas, Rio de Janeiro, v. 1, n. 30, p. 123-151, 2017. Disponível em: <https://bit. ly/2UbWbdK>. Acesso em: 9 nov. 2020.

SANTI, Maria Angélica. Mobiliário no Brasil: origens da produção e da industrialização. São Paulo: Editora SENAC, 2013.

SILVA, M. Nogueira da. Pequenos estudos sobre arte: pintura esculptura. Rio de Janeiro: Editora Brasileira Lux, 1926.

SIMIONI, Ana Paula Cavalcanti. Profissão artista: pintoras e escultoras acadêmicas brasileiras. São Paulo: EDUSP, 2008.

Artigo apresentado em: 21/3/2020. Aprovado em 25/8/2020.

\section{(cc) BY}

All the contents of this journal, except where otherwise noted, is licensed under a Creative Commons Attribution Licens 